\title{
PIMM
}

\section{A Performance Improvement Measurement Methodology}

For Reporting to the DOE Chief Financial Officer

and Under the Government Performance and Results Act

U.S. Department of Energy

Office of Fossil Energy

Morgantown Energy Technology Center

P.O. Box 880

Morgantown, West Virginia 26507-0880

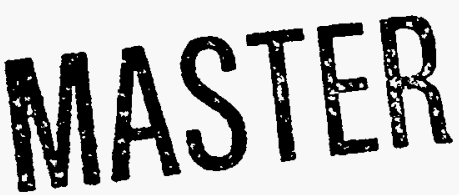

May 15, 1994

DISTRIBUTION OF THIS DOCUMENT IS UNLIMITED

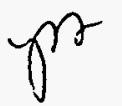




\section{DISCLAIMER}

This report was.prepared as an account of work sponsored by an agency of the United States Government. Neither the United States Government nor any agency thereof, nor any of their employees, make any warranty, express or implied, or assumes any legal liability or responsibility for the accuracy, completeness, or usefulness of any information, apparatus, product, or process disclosed, or represents that its use would not infringe privately owned rights. Reference herein to any specific commercial product, process, or service by trade name, trademark, manufacturer, or otherwise does not necessarily constitute or imply its endorsement, recommendation, or favoring by the United States Government or any agency thereof. The views and opinions of authors expressed herein do not necessarily state or reflect those of the United States Government or any agency thereof. 


\section{DISCLAIMER}

Portions of this document may be illegible in electronic image products. Images are produced from the best available original document. 


\section{Table of Contents}

Page

EXECUTIVE SUMMARY $\ldots \ldots \ldots \ldots \ldots \ldots \ldots \ldots \ldots \ldots \ldots \ldots$

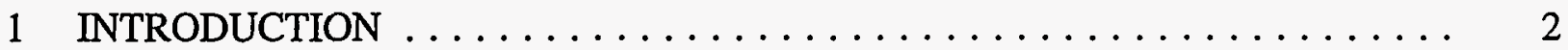

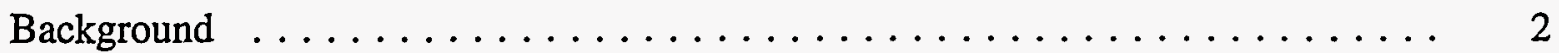

The Charter and Goal . . . . . . . . . . . . . . . . . . . . . . 2

Performance Improvement Measurement Methodology (PIMM) . . . . . . . . . 3

Requirements for Performance Measures $\ldots \ldots \ldots \ldots \ldots \ldots \ldots$

The $\operatorname{Report} \ldots \ldots \ldots \ldots \ldots \ldots \ldots \ldots \ldots \ldots \ldots \ldots \ldots \ldots$

Proper Use and Improvement of PIMM $\ldots \ldots \ldots \ldots \ldots \ldots$

2 A GENERAL METHODOLOGY FOR PERFORMANCE MEASUREMENT . . . . 5

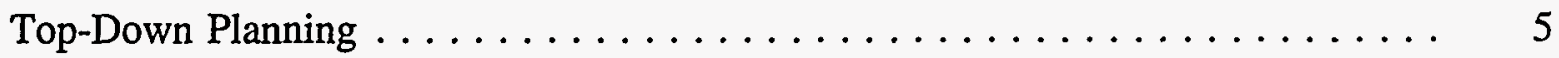

Major Areas of Performance - The METC Mission Hierarchy . . . . . . . . . . . 7

Bottom-Up Measurement: The Performance Based Indicator System (PBIS) . . . 8

Key Indicators for Institutional Mission . . . . . . . . . . . . . . . . 11

Risk Reduction as a Surrogate Measure for Technology Progress . . . . . . . . . 12

Cost Performance and Reporting ...................... 13

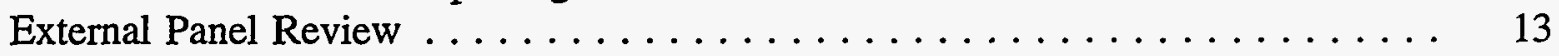

Critique and Application to Reporting $\ldots \ldots \ldots \ldots \ldots \ldots$

3 REPORT FORMATS ........................... 15

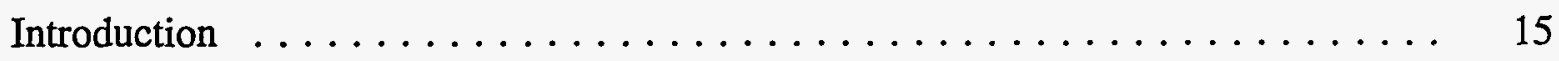

Quarterly Reports .............................. 15

Annual Reports to the Headquarters Program Offices . . . . . . . . . . . . . 15

Program Office Report . . . . . . . . . . . . . . . . . . . . 22

4 IMPLEMENTATION SCHEDULE $\ldots \ldots \ldots \ldots \ldots \ldots \ldots \ldots \ldots \ldots$

APPENDIX A: APPLICATIONS TO METC MEASUREMENTS . . . . . . . . . 31

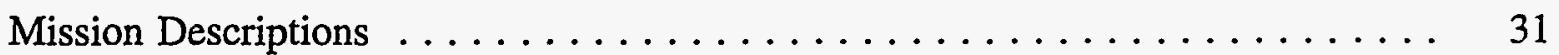

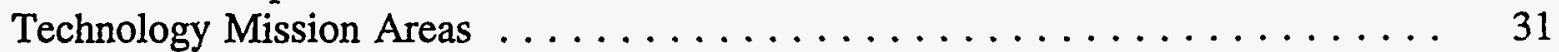

The IGCC Mission Area . . . . . . . . . . . . . . . . . . . . 32

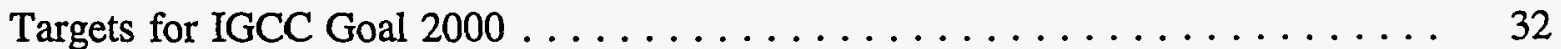

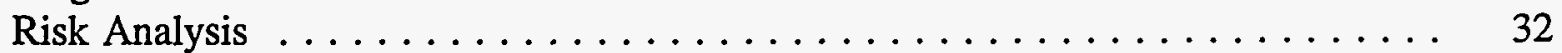

Cost Performance . . . . . . . . . . . . . . . . . . . . . . . . 34

Target Performance for IGCC Goal 2000 - Third Year of Program (1995) . . . . 34

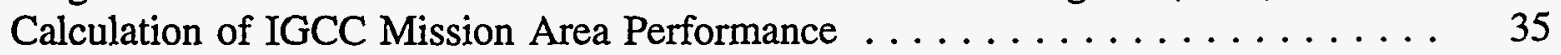

Calculation of Technology Mission Performance $\ldots \ldots \ldots \ldots \ldots \ldots \ldots \ldots \ldots$ 


\section{Table of Contents}

(Continued)

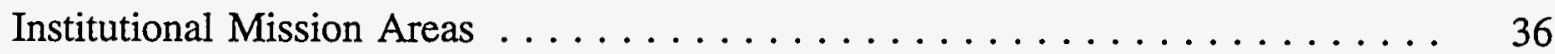

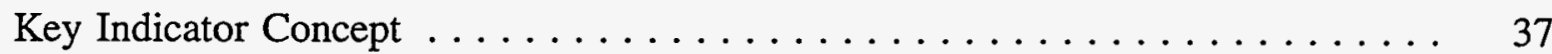

Environment, Safety, and Health (ES\&H) Mission Area . . . . . . . . . . . . 38

Management and Culture Mission Area . . . . . . . . . . . . . . . . . . . 40

Technical and Resource Management Mission Area . . . . . . . . . . . . . 43

External Relationships Mission Area . . . . . . . . . . . . . . . . 44

Rollup to Institutional Mission Level $\ldots \ldots \ldots \ldots \ldots \ldots \ldots \ldots \ldots$

Reporting ............................ 44

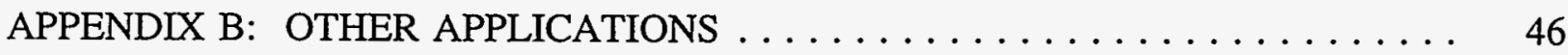

Strategic Petroleum Reserve Office $($ SPRO) $\ldots \ldots \ldots \ldots \ldots \ldots$

Office of Fossil Energy $\ldots \ldots \ldots \ldots \ldots \ldots \ldots \ldots \ldots$

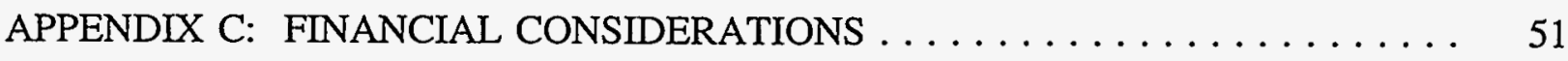

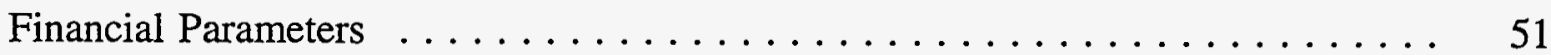

Reporting Options ........................... 51

Data Collection Guidelines $\ldots \ldots \ldots \ldots \ldots \ldots \ldots \ldots \ldots \ldots \ldots \ldots \ldots$

APPENDIX D: GLOSSARY OF TERMS .................. 54

APPENDIX E: EXAMPLE RISK ANALYSIS FOR IGCC GOAL \#1 (GOAL 2000) . 58

APPENDIX F: PERFORMANCE BASED BUDGETING $\ldots \ldots \ldots \ldots \ldots$

\section{List of Figures}

Figure $\quad$ Page

2.1 Flow Diagram of METC's Measurement Methodology . . . . . . . . . 5

2.2 Hierarchy From Organizational Mission to Targets $\ldots \ldots \ldots \ldots \ldots$

$2.3 \quad$ METC Hierarchy $\ldots \ldots \ldots \ldots \ldots \ldots \ldots \ldots \ldots \ldots \ldots \ldots \ldots$

$3.1 \quad$ Illustration of Quarterly Report Format $\ldots \ldots \ldots \ldots$

3.2 Overview of Contents of METC's Annual Report $\ldots \ldots \ldots \ldots 17$ 


\section{List of Figures}

(Continued)

\section{Figure}

3.3 Overview of Contents of FE's Annual Report . . . . . . . . . . . . 22

$4.1 \quad$ METC GPRA Pilot Implementation Structure $\ldots \ldots \ldots \ldots \ldots \ldots$

$4.2 \quad$ Flow Diagram of PIMM Implementation $\ldots \ldots \ldots \ldots \ldots$

A.1 Planned Risk Reduction Profile Through RD\&D . . . . . . . . . . . 33

A.2 Example of a Key Indicator Trend $\ldots \ldots \ldots \ldots$

B.1 Rollup for FE Mission $\ldots \ldots \ldots \ldots \ldots \ldots \ldots \ldots$

\section{List of Tables}

Table

Page

$2.1 \quad$ PBIS for Target Achievement $\ldots \ldots \ldots \ldots \ldots \ldots \ldots$

$2.2 \quad$ PBIS for Target Priorities $\ldots \ldots \ldots \ldots \ldots \ldots \ldots$

2.3 Target Achievement Score Calculation Using PBIS $\ldots \ldots \ldots \ldots \ldots$

$2.4 \quad$ PBIS for the Technology Mission $\ldots \ldots \ldots \ldots \ldots \ldots$

$3.1 \quad$ PBIS for the FE Technology Mission $\ldots \ldots \ldots \ldots \ldots$

4.1 METC GPRA Pilot Implementation Schedule for FY94 . . . . . . . . . . 30

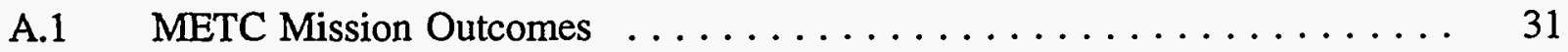

A.2 METC Technology Mission Areas or Product Lines $\ldots \ldots \ldots \ldots \ldots \ldots$

A.3 IGCC Mission Area Goals $\ldots \ldots \ldots \ldots \ldots \ldots \ldots \ldots \ldots \ldots \ldots \ldots \ldots$

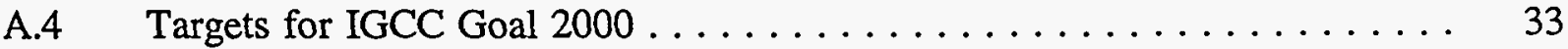

A.5 Performance for IGCC Goal 2000, Third Year of Program . . . . . . . . . 35

A.6 Determination of Mission Area Performance and Cost Performance Scores . 35 


\section{List of Tables}

(Continued)

Table

Page

A.7 Determination of Technology Mission Performance . . . . . . . . . 36

A.8 Institutional Mission, Mission Areas, Goals, and Key Indicators . . . . . . 39

A.9 Target Achievement for ES\&H Goal 1 - Risk Minimization . . . . . . . 41

A.10 Calculation of Mission Area Scores for ES\&H $\ldots \ldots \ldots \ldots \ldots \ldots$

A.11 Key Indicator Scores for the ES\&H Mission Area . . . . . . . . . . . 42

A.12 Target Achievement for Year 1 for Goal "Achieve and Maintain 'Master' Status in TQM ......................... 42

A.13 Calculation of Management and Culture Mission Area Target Achievement

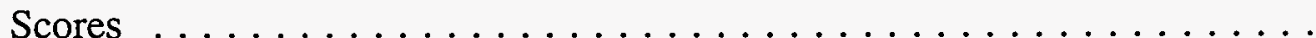

A.14 Determination of Key Indicator Score for the Management and Culture Mission Area Using Presidential Award for Quality Criteria . . . . . . . . . . 43

A.15 Key Indicators for Management and Culture Mission Area . . . . . . . . . 44

A.16 Performance Based Indicator System for Institutional Mission $\ldots \ldots \ldots$

A.17 Institutional Mission Annual Report . . . . . . . . . . . . . . 45

B.1 Target Achievement Performance Evaluation for Production Capability

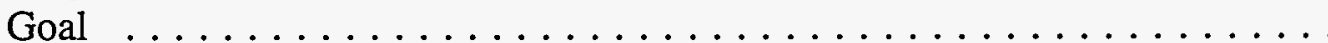

B.2 Goal Scores for SPRO Technology Mission $\ldots \ldots \ldots \ldots \ldots$

B.3 PBIS for SPRO Technology Mission $\ldots \ldots \ldots \ldots \ldots \ldots \ldots$

B.4 Individual Performance for FE Reporting Elements . . . . . . . . . . . . 49

B.5 Performance Based Indicator System for the FE Technology Mission _. . . 49

B.6 PBIS for the FE Institutional Mission $\ldots \ldots \ldots \ldots \ldots \ldots \ldots$

E.1 Example Risk Analysis for a Specific IGCC System: Technology Risk Related to User Requirements 


\section{Executive Summary}

This report presents a Performance Improvement Measurement Methodology (PIMM) for measuring and reporting the mission performance for organizational elements of the U.S. Department of Energy to comply with the Chief Financial Officer's Act (CFOA) of 1990 and the Government Performance and Results Act (GPRA) of 1993. The PIMM is illustrated by application to the Morgantown Energy Technology Center (METC), a Research, Development and Demonstration (RD\&D) field center of the Office of Fossil Energy, along with limited applications to the Strategic Petroleum Reserve Office and the Office of Fossil Energy. METC is now implementing the first year of a pilot project under GPRA using the PIMM. The PIMM process is applicable to all elements of the Department; organizations may customize measurements to their specific missions.

The PIMM has four aspects: (1) an achievement measurement that applies to any organizational element, (2) key indicators that apply to institutional elements, (3) a risk reduction measurement that applies to all RD\&D elements and to elements with long-term activities leading to riskassociated outcomes, and (4) a cost performance evaluation. Key Indicators show how close the institution is to attaining long range goals. Risk reduction analysis is especially relevant to $R D \& D$. Product risk is defined as the chance that the product of new technology will not meet the requirements of the customer. RD\&D is conducted to reduce technology risks to acceptable levels. The PIMM provides a profile to track risk reduction as RD\&D proceeds. Cost performance evaluations provide a measurement of the expected costs of outcomes relative to their actual costs.

The PIMM requires inputs from the organization's strategic and multi-year operational plans that normally exist under sound management practices. The PIMM uses these plans to determine operational and institutional missions/goals with demonstrable outcomes or "products" that may be delivered over periods of years. Intermediate targets allow more frequent measurements to be made. Progress toward achieving the targets is measured by Performance Based Indicator System (PBIS) descriptors with associated numerical ratings. The measurements for targets are then easily rolled up into measurements for goals and then to mission areas and missions, and thus to the organization's overall performance.

Each organizational element provides performance data to the headquarters program office on a quarterly basis and also in a comprehensive annual report. An external team, comprised of customers, headquarters managers, and field peers of the organizational element, provides an independent annual audit of the validity and quality of the PIMM application. The headquarters office then rolls up the results for all reporting elements for quarterly and annual reports.

All organizations exist to conduct certain activities intended to yield mission outcomes, and all organizations make internal judgments about performance. The PIMM can help all organizational elements to measure effectiveness in carrying out missions. The results of measurements should not be used to annually reward high scoring organizations or punish low scoring organizations, although organizations that show unfavorable long term trends should view the trends as a "wake up call" for improvement. The PIMM measures emphasize mission achievement rather than counting outputs, and the focus is on performance improvement, consistent with modern Quality Management principles. 


\section{Introduction}

\section{Background}

There is an increasing need that governmentfunded Research, Development and Demonstration (RD\&D) programs must yield outcomes that serve national needs. The Chief Financial Officer's Act (CFOA) of 1990 requires the CFO of each Federal department or agency to "develop and maintain an integrated agency accounting and financial management system, including financial reporting and internal controls, which provides for the systematic measurement of performance." The Act has no guidance on the form or content of the performance report or for specific measurement parameters. The Government Performance and Results Act (GPRA) of 1993 goes further in requiring government agencies to measure performance, and allows agencies to establish "pilot" programs for performance measurements. In the time between the first version of this report and now, METC has been accepted as a pilot under GPRA.

In early 1993, the U.S. Department of Energy's CFO requested the Assistant Secretary for Fossil Energy (ASFE) to pilot the development of performance measures within the Department. The ASFE then appointed a Fossil Energy (FE) core group consisting of a Chairperson from FE headquarters staff, a representative from each FE Deputy Assistant Secretary, and a representative from each of the two FE Energy Technology Centers to be responsible for the pilot venture.

METC recognized this opportunity to provide a "showcase" example of a method of performance measurement that could be applied to any RD\&D environment. METC proposed to develop a prototype measurement and reporting system. This proposal was approved by the ASFE.
METC had established an internal Total Quality Management (TQM) performance measurement team to develop a measurement methodology that would identify processes and outcomes (products) to be measured, and to recommend procedures for making the measurements. This existing team was given the assignment to address the CFO Act requirements. The team selected an external expert, Dr. Jack Byrd of the Center for Entrepreneurial Studies and Development, Inc. at West Virginia University, with broad knowledge and expertise in the area of performance measurement, to facilitate the work and provide an independent quality check of the team product.

Once the initial phase of the study was completed in June 1993, the team continued without the consultant to improve and revise the plan, and to address the requirements of the GPRA.

\section{The Charter and Goal}

The team charter defined the area to be investigated, the project goal, and the boundaries and scope of the assignment. The goal of the project was two-fold: first, to comply with the new laws requiring a system to assess the effectiveness and efficiency of the Department's programs in fulfilling its mission; and, secondly, to develop measurements that provide a means to characterize METC's management and operational "systems", as defined conceptually by the late W. Edwards Deming, the premier spokesperson for $\mathrm{TQM}$, so that efforts to improve quality could be objectively evaluated.

The development of performance-based measurements and a system to report them was recognized as the team's focus for this report. The intent was to develop a system to measure the timely, efficient, and cost-effective delivery of quality products and services to METC's 
customers, especially to its private sector partners. The methodology uses information from existing management systems, such as strategic and operational plans that are already required by the Department as sound management practices.

Rather than simply counting outputs against inputs, customer-oriented outcomes were sought, and measurements were developed to track progress toward their eventual transfer to the customers and into commercial practice. The longterm nature of the outcomes required short- and intermediate-term measures to be developed, such as the concept of technology risk reduction, which is a surrogate for long-term outcomes such as market penetration. The approach also suggests a measurement to evaluate the cost performance of activities. The resulting methodology is believed to be applicable to FE and throughout the Department.

METC followed the legislative history of the GPRA and attempted to align the performance measurements in this report with the intent of the GPRA. Once the GPRA had passed into law, METC proposed through DOE Headquarters to participate as a pilot program. This proposal was accepted by the Office of Management and Budget (OMB) and the pilot program is now beginning its first year of implementation. A separate performance plan is being prepared for the pilot program.

\section{Performance Improvement Measure- ment Methodology (PIMM)}

The approach developed by the team and presented here uses measures which are meaningful in all RD\&D environments as well as for organizational elements with a service mission. Using measures that are forward-looking, the methodology is designed to aid in improving future performance rather than to be solely a scorecard for past activities. Thus, it is named the Performance Improvement Measurement Methodology (PIMM).

\section{Requirements for Performance Measures}

The design requirements described below guided the development of the PIMM. These requirements are similar to Baldridge Award criteria which emphasize strategic planning and a TQM focus on the customer.

- Outcome versus Output focus - Rather than counting outputs (e.g., number of papers presented), the focus is on how RD\&D expenditures are used to reduce the risk for new technology to a level acceptable for commercialization.

- Customer Emphasis - Inputs from customers of the product must drive the RD\&D processes. With the PIMM, customers participate in independent annual reviews of the past year's measurements and achievements and the plans for the coming year.

- Cost Performance - Besides technical performance, the PIMM offers a method for evaluating cost performance of each activity.

- Focus on Significance - The PIMM uses a hierarchy with several different levels to organize reporting of measurements, and strives to limit the number of performance measures for a given level, by focussing on the "essential few" performance areas that make a difference.

- Strategic and Operational Planning - The PIMM mainly uses data that should already exist in strategic plans or multi-year operational plans, and can accommodate the integration of existing reviews into the performance measurement system (e.g., 
Environment, Safety \& Health [ES\&H] reviews).

- Simple to Understand - No aspect of the performance measurements requires special skills.

- Compatible with All Program Time Horizons - The PIMM measures can be used for quarterly or annual reporting even though their focus is long term (e.g., 2010 when applied to METC).

- TQM Approach - The PIMM presumes continuous performance improvement at all levels in the organization. Performance feedback and recommendations for improvement are supplied by external reviewers, customers, management, and empowered employees.

\section{The Report}

This report is the measurement team's product that presents the PIMM: Section 2 illustrates the methodology with a METC-based example; Section 3 presents a mock-up of quarterly and annual performance reports; Section 4 shows METC's implementation schedule; and Appendices A, B, C, D, E, and F describe the details of the METC application, illustrate how the PIMM might be transferred to $\mathrm{FE}$ as well as other organizational entities within the Department, describe financial considerations and other supporting information, define terms, explain the risk analysis methodology, and discuss performance based budgeting.

The applications to METC and other organizations are hypothetical and are used solely to illustrate the methodology. Although they are based on actual plans and other documents, they must not be taken as "official".
The PIMM system is built on simple concepts. Once the concepts of Section 2 are grasped, the reporting formats in Section 3 can be easily understood. Much of the text and tables in the Appendices deal with illustrating applications to show the PIMM's flexibility and effectiveness. The PIMM is recommended as the standard measurement methodology for the Department.

\section{Proper Use and Improvement of PIMM}

The PIMM has sufficient flexibility to allow an organization to manipulate the performance criteria and results, which would defeat the intent to measure and report real Mission progress. Very high scores in all areas of measurement might be an indication that bias is occurring or that targets or cost estimates are being set very conservatively. The external review offers an opportunity to identify whether manipulation has occurred. This situation might be expected if the performance measurements report is used to rebuke or punish an organization that shows slow progress on a difficult mission, or to excessively reward an organization that shows high performance for a routine mission. If the reporting process focuses on improving the management systems that impact Mission performance, a more forthcoming report should be expected. The focus upon improving Mission performance must be emphasized in implementation of the measurement process.

Continuous improvements in the measurement methodology will prevent the process from becoming obsolete. Recommendations for improvements are expected to come from both internal organizational users of the PIMM and from the external review panel. 


\section{A General Methodology for Performance Measurement}

\section{Top-Down Planning}

A top-down approach is used to define the measurement hierarchy, beginning with the organization's Mission, the strategic plan, and other planning documents. Once the hierarchy is established, a bottom-up approach is then used to make the actual measurements and roll them up through the hierarchy to determine Mission performance.

Figure 2.1 is a flow diagram of the PIMM approach, illustrating the steps involved in implementing the methodology. While this

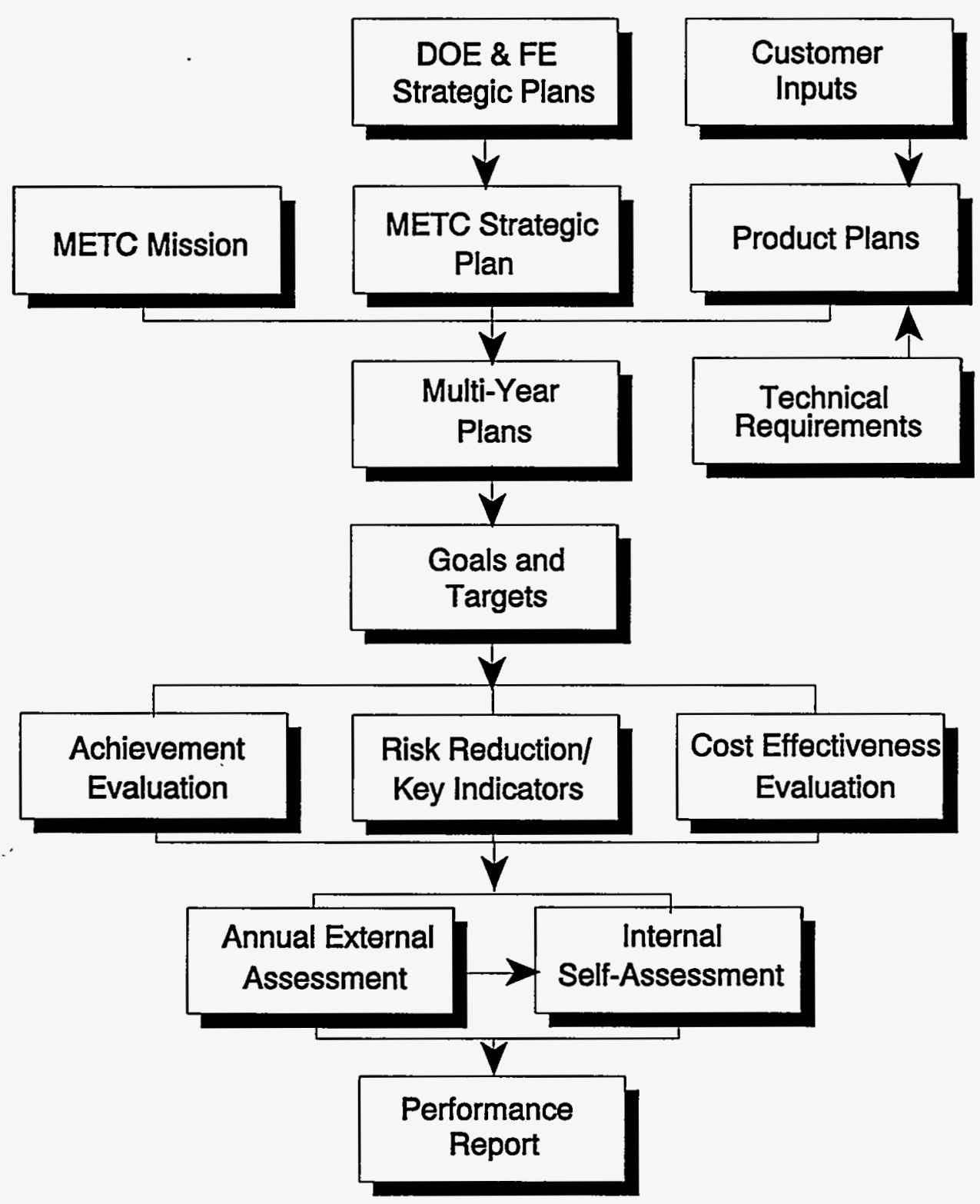

Figure 2.1. Flow Diagram of METC's Measurement Methodology 
approach was developed specifically for METC, it is relevant to all DOE organizational elements.

The PIMM begins with the "Mission" of the organization to derive the structure of activities. Missions are contained in the organization's strategic plan; they reflect the reasons for the organization's existence. There may be separate Technology and Institutional Missions, each of which may include several "Mission Areas". Mission Areas are defined in two ways in this report. For the Technology Mission, they are the major technology products for eventual delivery to internal or external customers. For the Institutional Mission, they are the major functions that are needed to carry out the organization's activities. "Goals" are established under each of the Mission Areas. Goals are typically specific long-term outcomes, such as market penetration for a new technology.

The bases for achievement measures are usually "Targets" that reflect specific outcomes to be achieved in support of the Goals. Targets may represent the end products of individual tasks (or activities) or collections of tasks (e.g., completion of a product plan, construction of a new facility). The Targets arise from operational plans and are chosen by those managing the activity.

A generalized diagram of the top-down approach for the measurement structure from Mission to Target level is presented in Figure 2.2. This general structure applies to both Technology and Institutional Missions. Remember that the

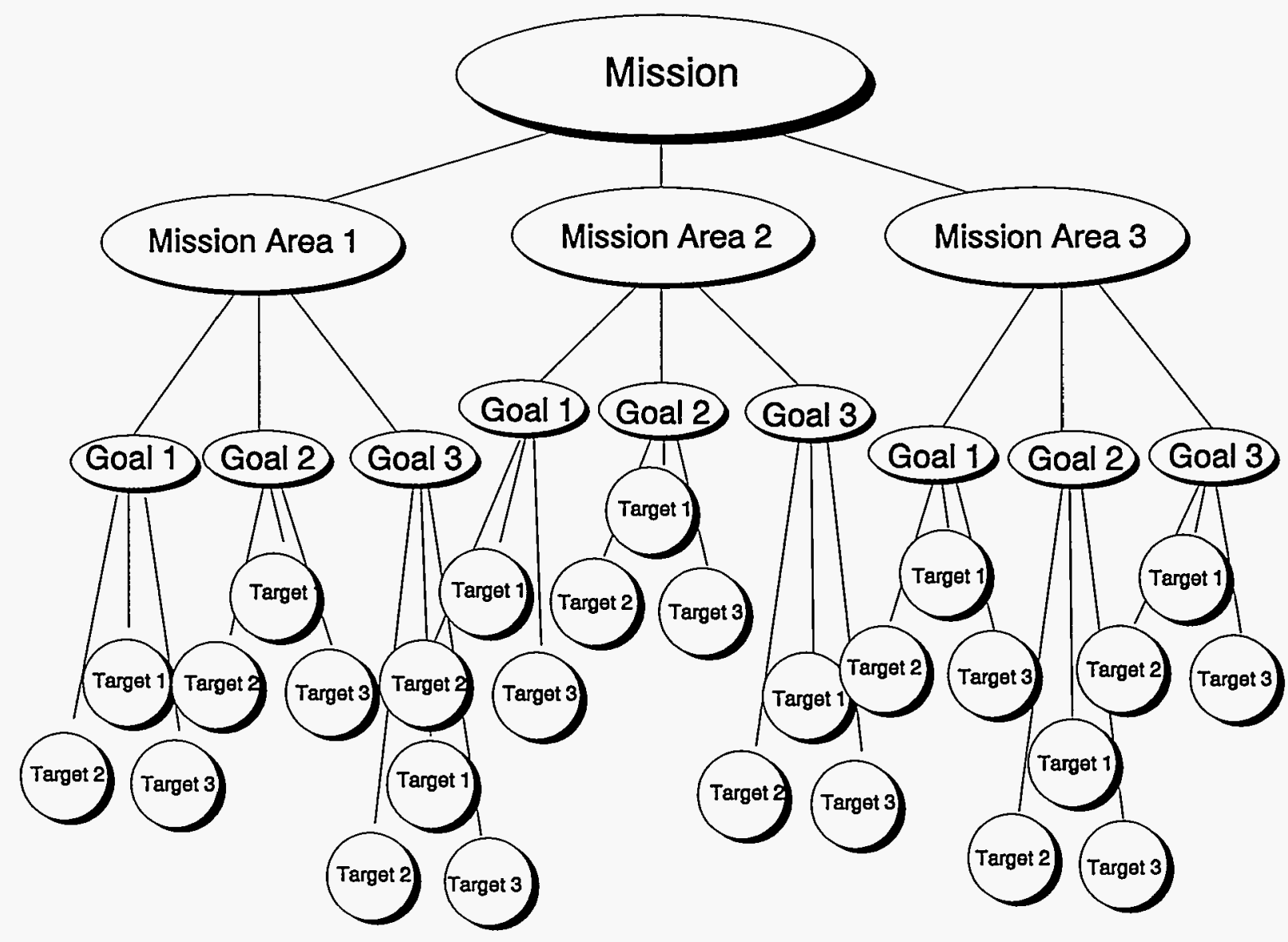

Figure 2.2. Hierarchy From Organizational Mission to Targets 
structure is defined by a top-down planning process, while the measurement process begins at the bottom level (Targets) and flows up through the structure.

The hierarchy in Figure 2.2 shows increasing specificity and measurability, proceeding from the Mission to Mission Areas to Goals to Targets. This diagram shows only three expansions at each lower level. More expansions could be made at each level, potentially giving a large number of measurements, but choices may also be made to limit the Targets. A limit of six expansions at each lower level is recommended. The PIMM facilitates roll up of Target measurements into Goals, then into Mission Areas and finally Missions. This roll up reduces the number of measurements that must be reported for each organization.

\section{Major Areas of Performance - The METC Mission Hierarchy}

Application of the PIMM normally includes performance for both Technology and Institutional Missions. This dual Mission is illustrated for METC as an example in Figure 2.3.

METC's overall Mission statement is "Enhance the United States' economic competitiveness, environmental quality, and national security and standard of living through development and deployment of the world's cleanest, lowest cost, most reliable, and most efficient technological products for producing and utilizing domestic fossil fuels."

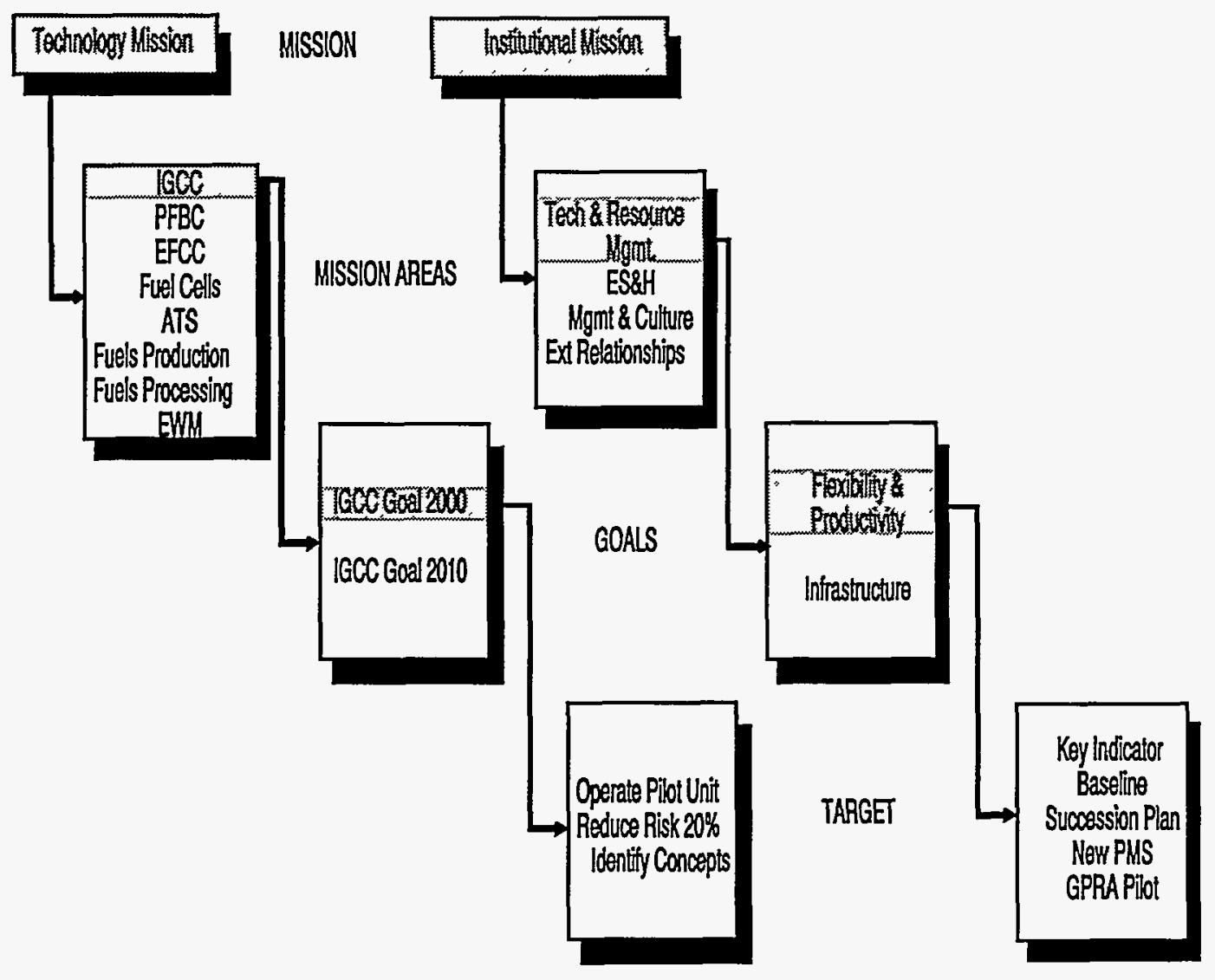

Figure 2.3. METC Hierarchy 
The METC Technology Mission focuses on the development of eight major Mission Areas or products. Five are systems for generation of electric power: Integrated Gasification Combined Cycle (IGCC); Pressurized Fluidized Bed Combustion (PFBC); Externally Fired Combined Cycles (EFCC); Advanced Turbine Systems (ATS); and Fuel Cells. The other products are Fuels Production, Fuels Processing, and Environment and Waste Management (EWM).

METC's Institutional Mission is to provide the infrastructure and capabilities necessary for the Technology Mission to be performed, including the Mission Areas of Environment, Safety, and Health (ES\&H), Management and Culture, Technical and Resource Management, and External Relationships.

Figure 2.3 shows an abbreviated example of the METC Mission hierarchy. To simplify the illustration, only IGCC is expanded from the Technology Mission Area level to the Goal level and then to the Target level. That is, the IGCC Mission Area is expanded into separate Goals. Each Goal is only titled in this illustration: each Goal is only complete when its own set of technical requirements and time requirements are specified, as described in Appendix A. For example, the Goal 1 statement for the IGCC system is "By year 2000, 1,500 megawatts of cumulative IGCC capacity will be ordered for delivery by 2005, based on IGCC system with efficiency of $45 \%$, cost of $\$ 1200 / \mathrm{kW}$, and environmental emissions 1/10th of federal regulations."

Working down the table, the Target levels represent the activities needed to achieve the IGCC Goal 1 requirements. Specific intermediate- and near-term Targets are identified to bring about successful accomplishment of each Goal. Targets are similar to milestones that must be accomplished along the development path to meet the Goal as identified in approved operational RD\&D plans.
A similar limited level of detail is provided in Figure 2.3 for the METC Institutional Mission.

\section{Bottom-Up Measurement - The Perfor- mance Based Indicator System (PBIS)}

When measurements are to be made and reported, the path in Figure 2.3 is retraced upward from Targets through intermediate levels to Missions. Performance measurement begins with the most basic units, Targets. The organization earns scores associated with different levels of Target achievement. The term "Target achievement" is used at all levels for the rolled up score based on Targets, in order to avoid confusion with other performance measures which are used at these higher levels. The Target scores are rolled up to determine the level of Target achievement for the Goal. The roll up then continues to measure the Mission Area performance using achievement scores of each of the Goals within it, and concludes with the evaluation of the performance of each Mission by rolling up the Mission Area scores. The overall performance of an organization is represented by the Technology Mission performance and the Institutional Mission performance.

These results are not combined into a composite measure; normally, the Technology Mission performance is the measure of primary interest to the Congress or Administration officials.

The measurement of Target achievement is one of the key aspects of the PIMM, and the instrument to translate actual performance into a quantified performance level is the Performance Based Indicator System (PBIS). The PBIS defines the criteria required to achieve userspecified performance levels. A PBIS consists of a set of three to five performance descriptors that can be used to assess achievements for a specific activity. The application can be at any level; Target, Goal, Mission Area, or Mission. 
At the Target level, a PBIS defines a scale for evaluating Target achievements and the priority of each Target. The prototype proposed by METC to measure Target Achievement is to establish five performance levels that apply to any Target, simply indicating a percentage achievement of the desired result, in terms of quality, quantity, and timeliness. The recommended PBIS for Target achievement is shown in Table 2.1. Each performance level has a numerical and narrative description. The rater examines what was done and uses the description to pick a Target Achievement score.

The importance of achieving each Target can be expressed in a PBIS priority table, as shown below in Table 2.2. This PBIS defines three priority levels: high, medium and low, and assigns weights to each level, weighted toward higher importance. This allows the manager to distinguish between Targets of major and minor importance.

Table 2.1. PBIS for Target Achievement

\begin{tabular}{||c|l||}
\hline $\begin{array}{c}\text { Target } \\
\text { Achievement } \\
\text { Score }\end{array}$ & \multicolumn{1}{|c|}{ Target Achievement Description } \\
\hline 90 to 100 & $\begin{array}{l}\text { The Target was satisfactorily achieved. Little or no wrap-up work is } \\
\text { needed. }\end{array}$ \\
\hline 70 to 89 & $\begin{array}{l}\text { The Target was nearly achieved; only minor and obvious work } \\
\text { remains to completion. }\end{array}$ \\
\hline 50 to 69 & $\begin{array}{l}\text { A major part or fraction of the Target was achieved, but significant } \\
\text { work remains to achieve the Target completely. }\end{array}$ \\
\hline 30 to 49 & $\begin{array}{l}\text { The Target was attempted, but the end result was unsatisfactory. } \\
\text { Major work remains to achieve a satisfactory result. }\end{array}$ \\
\hline 0 to 29 & $\begin{array}{l}\text { The Target was not attempted or attempted without results } \\
\text { forthcoming. }\end{array}$ \\
\hline \hline
\end{tabular}

Table 2.2. PBIS for Target Priorities

\begin{tabular}{||c|c|l||}
\hline Priority & Weight & \multicolumn{1}{c|}{ Description } \\
\hline High & 9 & $\begin{array}{l}\text { A critical activity. If this Target is not achieved, } \\
\text { the entire program may suffer and fail. }\end{array}$ \\
\hline Medium & 3 & $\begin{array}{l}\text { An important activity. If this Target is not } \\
\text { achieved, other aspects of the program will } \\
\text { suffer. }\end{array}$ \\
\hline Low & 1 & $\begin{array}{l}\text { An important activity, to be done if time and } \\
\text { resources permit. If this Target is not achieved, } \\
\text { the program will have a tolerable loss. }\end{array}$ \\
\hline
\end{tabular}


The priority weights are selected to keep the scoring system in whole numbers and in a reasonable range. The weight range illustrated here strongly favors achieving the most important Targets.

The Targets for each Goal are given achievement scores using Table 2.1. These Target scores are multiplied by the priority weights to calculate an overall achievement score for each Goal. A hypothetical illustration is provided in Table 2.3 for a Goal supported by five Targets.

First, the level of achievement is estimated for each Target and entered in the table. The priority weights are multiplied by the achievement to yield total points for each Target. The Target points are summed and divided by the total of the priority weights, resulting in a overall achievement score for the Goal (for this example) of 79 .

Program strategies must be considered in the approach to roll up of Goal-level Target achievement scores to the Mission Area level. If, for example, the success of any one of the Goals satisfies the Mission Area for IGCC (assuming only one system would be marketed), then the highest of the Goal-level scores could be used at the Mission Area level. If all products are expected to be marketed at different times, it is appropriate to average Goal-level achievement scores to determine Mission Area performance. The averaging approach applies to IGCC (the example used here) because the IGCC products are expected to be introduced at progressively later times with better technical performance for the later products, and all products should obtain market share.

In the Technology Mission, at the Goal level, the concept of technology risk reduction is introduced and combined with the Goal-level Target achievement score. For the Institutional Mission, key indicators are defined at the Goal level and used as separate measures. At the Goal or Mission Area level, cost performance is evaluated and included as a measurement. The risk reduction, key indicator, and cost performance concepts are defined in later parts of this section. The Goal and Mission Area scores represent performance as a level of achievement and are normally expressed on a scale of zero to one hundred.

Table 2.3. Target Achievement Score Calculation Using PBIS

\begin{tabular}{||l|c|c|c|c||}
\hline \multicolumn{1}{|c|}{ Target Description } & $\begin{array}{c}\text { Target } \\
\text { Priority }\end{array}$ & $\begin{array}{c}\text { Target } \\
\text { Weight }\end{array}$ & $\begin{array}{c}\text { Target } \\
\text { Achievement }\end{array}$ & $\begin{array}{c}\text { Target } \\
\text { Points }\end{array}$ \\
\hline Hot cleanup proof of concept tests & $\mathrm{H}$ & 9 & 100 & 900 \\
\hline Demonstration unit design & $\mathrm{M}$ & 3 & 50 & 150 \\
\hline Particle removal proof of concept tests & $\mathrm{M}$ & 3 & 100 & 300 \\
\hline $\begin{array}{l}\text { Lab scale Hazardous Air Pollutants } \\
\text { tests }\end{array}$ & $\mathrm{H}$ & 9 & 50 & 450 \\
\hline $\begin{array}{l}\text { Successful Demonstration unit } \\
\text { operation }\end{array}$ & $\mathrm{H}$ & 9 & 90 & 810 \\
\hline \hline \multicolumn{1}{|c|}{ Totals } & & $\mathbf{3 3}$ & & $\mathbf{2 6 1 0}$ \\
\hline
\end{tabular}

Overall Target Achievement Score for Goal $=(2610 / 33)=79$ 
For the Mission level roll up, the use of a Mission PBIS allows a "reality check" to ensure that the scores represent real outcomes and Mission progress, rather than simply a mechanical averaging of lower level scores. Because it is needed to understand the Performance Report illustrations presented in Section 3, the PBIS for METC's Technology Mission is shown in Table 2.4. The Technology Mission performance is measured on a scale defined at "levels" ranging from ten down to two. The user determines the Technology Mission score by finding the PBIS level in the table corresponding to the Mission Area scores. Intermediate situations may be handled by interpolating between (or extrapolating beyond) the defined numerical levels. This is only one example of possible systems that could be developed; this particular PBIS emphasizes the METC Mission Areas which include products in the Power System business sector. This generic PBIS description is recommended for standard usage in the Department.
A similar PBIS approach is used to roll up Institutional Mission Area scores to provide a Mission score. Since the Technology and Institutional Missions are disparate and serve different customers, further mathematical combinations make little sense. Technology and institutional Mission scores are separately reported, as illustrated in Section 3.

\section{Key Indicators for Institutional Mission}

Since the Target Achievement measure is primarily based on short term activities of typically one year duration, it does not directly measure the progress of the organization in attaining its long range Goals. A method is needed to characterize success of each Mission Area that is independent of short range measurements, and is more reflective of how close the institution is getting to the long range Goals of the Mission Area. The Key Indicator concept was developed to address this need.

Table 2.4. PBIS for Technology Mission

\begin{tabular}{|c|l|l||}
\hline Level & \multicolumn{1}{|c|}{ Generic PBIS } & \multicolumn{1}{|c|}{ METC Specific PBIS } \\
\hline 10 & Progress toward fulfilling Mission is excellent. & $\begin{array}{l}\text { Three Mission Areas with } \\
\text { scores }>90, \text { two are Power } \\
\text { Systems, one is an "other". }\end{array}$ \\
\hline 8 & $\begin{array}{l}\text { Mission is progressing well; minor corrective } \\
\text { work needed. }\end{array}$ & $\begin{array}{l}\text { Two Mission Areas with } \\
\text { scores }>80, \text { one is a Power } \\
\text { System, one is an "other". }\end{array}$ \\
\hline 6 & $\begin{array}{l}\text { Mission progress slowed; but potential barriers } \\
\text { and solutions are clearly identified. }\end{array}$ & $\begin{array}{l}\text { One Power System Mission } \\
\text { Area with rating }>80 .\end{array}$ \\
\hline 4 & $\begin{array}{l}\text { Mission progress slowed significantly, } \\
\text { solutions unclear. }\end{array}$ & $\begin{array}{l}\text { Two Mission Areas with } \\
\text { scores }>50, \text { one is a Power } \\
\text { System. }\end{array}$ \\
\hline 2 & $\begin{array}{l}\text { Mission progress stalled; major obstacles, no } \\
\text { evident solutions. }\end{array}$ & $\begin{array}{l}\text { No Mission Areas with } \\
\text { scores }>50\end{array}$ \\
\hline
\end{tabular}


"Key indicators" are high level measurements that relate closely to long range goal attainment. Trends of these key indicators are directly related to mission success. Key indicators will be "benchmarked"- i.e., there should be a way to compare the indicators with the performance of the best outside organizations, both within and without government.

Each of the Institutional Mission Areas (i.e., Technical and Resource Management, ES\&H, Management and Culture, and External Relationships) has a much greater degree of uniqueness than occurs among the Technology Mission Areas. The types of issues dealt with, the particular skills utilized, the identity of the external (and internal) customers, and the METC relationships impacted are all quite different for each of the Institutional Mission Areas. For this reason, a single Key Indicator cannot be used for all areas, and the Key Indicators must be customized for each Mission Area. The specific types of Key Indicators chosen are discussed further in Appendix A. A special Key Indicator was developed for the Technology Mission; this special indicator is called Risk. The Risk concept (see next section below) used in the Technology Mission does not apply in general to the Institutional Mission because the functions to be measured are supporting in nature and do not exhibit the same kind of Risk that is encountered in RD\&D.

\section{Risk Reduction as a Surrogate Mea- sure for Technology Progress}

Outcomes for technology progress, such as achievement of commercial market share by a new product, often are not realized for 15 to 20 years after RD\&D begins on a new technology concept. The PIMM uses a concept of risk management to provide interim measures of technology progress. For this analysis, risk is defined as "the likelihood of the new technology being unacceptable to the customer for the application intended at the planned time of deployment." It is important to understand that "the customer" in this instance is not the U.S. government or DOE, but the industry sectors that will eventually sell (and buy) the technology as part of their commercial practice. Every product under development by METC has key technical barriers which must be overcome if the technology is to meet its technical and economic requirements and be commercially viable. For each technical challenge, usually associated with system components, the degree of risk is a function of the severity of the technical challenge itself and the importance of the technical challenge to satisfying the requirements of the customer. Risk can be directly estimated only for a single technology or product and is thus measured at the Goal level of the METC hierarchy.

In terms of this risk concept, the purpose of $R D \& D$ can be expressed as reducing the risk to a level low enough to be acceptable to a company for a commercial venture. The risk level describes the state of technology development at each point in time. A risk reduction "profile", which is a graph of risk level as a function of time, can be developed for each product, assuming that an RD\&D plan is followed and is successful. RD\&D tasks can be started to solve the technical barrier problems that are responsible for high levels of risk. Then the actual risk reduction can be compared to that planned for the year to yield a risk reduction score. Risk reduction scores are included in the performance scores at the Goal level, and rolled up to Mission Area and Mission levels in a way similar to the Target achievement scores previously discussed. The methodology of risk analysis is used in Appendix A and described in more detail in Appendix E. The concept of risk reduction may not apply to many Institutional Mission activities. 


\section{Cost Performance and Reporting}

Extensive financial accounting data are already provided to the CFO on a monthly basis, and little added value would result from reporting this detailed information again. However, existing financial reporting structures reflect "administrative" activities rather than progress against Missions or products. Progress in obligating and costing funds is an aspect of the conduct of business, and the incurrence of costs as activities are executed has particular importance. Brief quarterly reports will be made on obligations, planned costs, and actual costs incurred for each Mission Area or Goal. Both obligations and costs can be presented and discussed at greater length in the annual report, including carryovers against forthcoming activities.

Evaluating the performance of Federal organizations should include cost effectiveness considerations as well as technical outcomes. Cost performance must be measured against a realistic benchmark. Benchmarks are readily available for activities like construction of a building, the manufacture of specific products, or carrying out repetitive services. However, benchmarks for RD\&D are often difficult to establish. An examination of the ultimate cost/benefits to society from a new technology to be deployed years hence (payback) is a useful test for justifying the technology development, but it does not contribute to a meaningful measure of implementation cost performance because it is unlikely to change on an annual basis.

Since projected cost estimates are made by project managers to estimate future needs and assure that planned activities will be paid for, they can serve as a benchmark for evaluating the cost performance of activities. For each Goal in the Technology Mission, risk reduction is the most important outcome on an annual basis. Therefore, for these Goals, Cost Performance is evaluated by comparing the planned costs for the actual risk reduction achieved to the actual costs incurred for that same risk reduction. Conceptually, this is significantly different from simply calculating the ratio of planned expenditures for a given time period to actual expenditures for that time period, in that an outcome (Risk Reduction) rather than time provides the baseline for the calculation. For the Institutional Mission, at the Goal or Mission Area level depending on availability of cost information, a Cost Performance parameter can be calculated by comparing the planned costs incurred to the actual costs for the same achievement level. These calculations are further discussed and examples are presented in Appendix A. This kind of evaluation would be presented only in the annual report.

\section{External Panel Review}

Self-appraisal is a valuable tool for performance improvement, but the customers' views of the organization's effectiveness is the most valid measure of Mission effectiveness. A panel that includes knowledgeable outside reviewers will be used to assist the reporting organization in providing an independent, objective and credible assessment of performance for Technology and Institutional Missions in the annual report. The panel should include external and internal customers, e.g. representatives from the headquarters program office and perhaps other DOE officials, and other relevant persons. The external review panel will assess the validity of the PIMM application and the accomplishments of the past year, including performance scores for Achievement, Risk Reduction, Key Indicators, and Cost Performance. The panel will also review METC's future plans in light of past progress to suggest performance improvements. The panel report will be used in developing the report to headquarters, and a summary of the panel report will also be provided in the annual report. 
Critique and Application to Reporting

The PIMM is based on information contained in the management documentation already required by the DOE. There is considerable flexibility in the design of a PIMM for each organization. Some initial work is needed to set up the Target and Risk tables for various Technology Mission products, and to identify Targets and Key Indicators for Institutional Mission Areas. Once they are established, they normally should only need to be adjusted each year. A side-benefit of the effort should be a better understanding of the most significant risks associated with technical activities and awareness of the organization's effectiveness in carrying out its Missions.

If the existing management documentation is meager or inadequate, the difficulty of installing the PIMM is a signal that work needs to be done in defining the organization's Mission and accountabilities. The customer feedback required in the process can be very valuable in making the organization more responsive to its customers.

The PIMM is intended to ease the reporting process; it provides background and a logical framework for reporting, but most of the background information in the PIMM would not be forwarded in the annual report. The following section is a mockup showing what the actual Quarterly and Annual Performance Reports might look like, first for METC, and then for all of Fossil Energy. The reader should note that, to fully understand the sources of the performance scores shown, he/she would need to read the organization's PIMM or applications guide. However, the mockups provide a grasp of the overall structure and are valuable in understanding additional details of the methodology that are presented later. 


\section{Report Formats}

\section{Introduction}

This section offers explicit formats for reports under CFOA and GPRA. The PIMM needs to be explained to all organizations that will use the methodology. An organization-specific applications guide will be needed to make the measurements and scores meaningful to readers. The guide will include the reporting hierarchies for both programmatic and institutional Missions, PBIS tables, and relevant risk profiles. If necessary, some PBIS tables can be appended to the annual report so that frames of reference are clear. A few PBIS tables have been identified in this report as desirable for universal use as a common basis of understanding upon which individual applications can be built.

The PIMM assumes that both the field and headquarters program offices will provide performance reports to a person in the program office responsible for preparing the Program Secretarial Officer (PSO) level report. That person then rolls the separate reports into a PSO level report of much less volume and detail. Quarterly reporting is recommended as the smallest interval for reporting; even over that interval, reportable performance progress may be minimal. A comprehensive annual report would replace the fourth quarter report.

\section{Quarterly Reports}

Each quarterly report should be very brief. The Technology Mission summary should not exceed one page. A similar summary would be written for the Institutional Mission. Thus, the entire quarterly report submitted to the headquarters program office would be only two pages per organizational element, as shown in Figure 3.1.

Each quarterly report will consist of a financial summary table, a brief narrative, and a bullet list

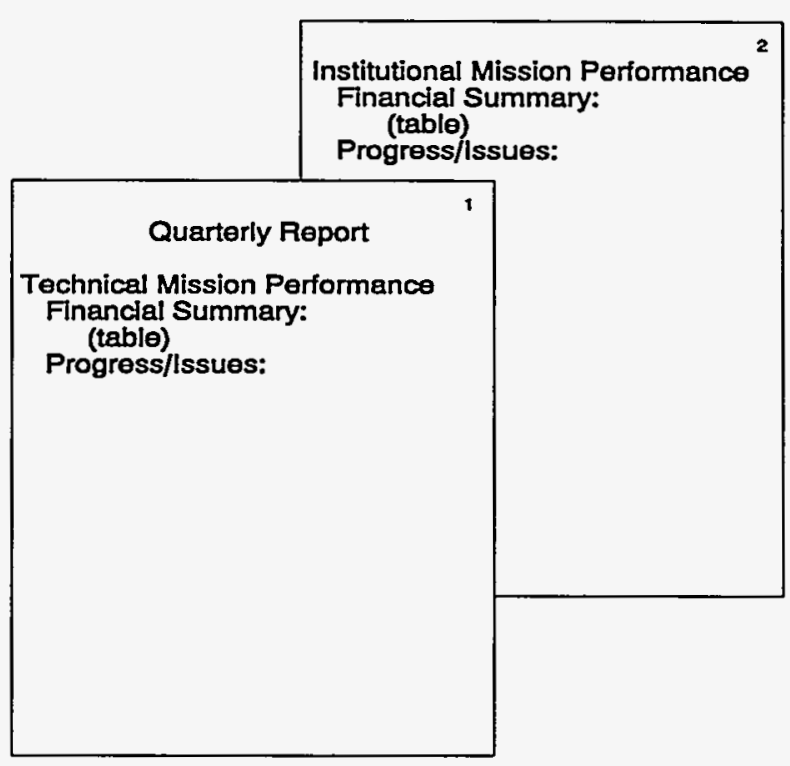

Figure 3.1. Illustration of Quarterly Report Format

highlighting the most important performancerelated items that occurred during the quarter. A sample layout is shown on the following page for the Technology Mission.

The headquarters office would prepare a twopage report for each Mission with all the budget information merged into one table, and accompanied by a very brief narrative and a selection of the most important office-level "bullets" for highlights of activities with the same format as shown. Thus each office-level report would be only four pages long, and the quarterly "paper load" for the Department's reports should be quite tractable.

\section{Annual Reports to the Headquarters Program Offices}

The annual performance measurements report to the headquarters program office would be more comprehensive, providing Mission performance scores as well as scoring tables at the Mission 


\section{Technology Mission Performance}

\section{Financial Summary (Millions of dollars)}

\begin{tabular}{||c|c|c|c|c|c|c|c||}
\hline $\begin{array}{c}\text { Technology } \\
\text { Mission } \\
\text { Area }\end{array}$ & $\begin{array}{c}\text { FY92 } \\
\text { Carryover }\end{array}$ & $\begin{array}{c}\text { FY93 } \\
\text { Budget } \\
\text { Authority }\end{array}$ & $\begin{array}{c}\text { FY93 } \\
\text { Planned } \\
\text { Obligations }\end{array}$ & $\begin{array}{c}\text { FY93 } \\
\text { Actual } \\
\text { Obligations }\end{array}$ & $\begin{array}{c}\text { FY93 } \\
\text { Planned } \\
\text { Costs }\end{array}$ & $\begin{array}{c}\text { FY93 Actual } \\
\text { Costs }\end{array}$ & $\begin{array}{c}\text { FY93 Cost } \\
\text { Sharing }\end{array}$ \\
\hline IGCC & 2.2 & 42.6 & 44.8 & 22.4 & 44.6 & 26.7 & 6.7 \\
\hline PFBC & 6.9 & 39.8 & 46.7 & 35.0 & 46.0 & 36.3 & 18.2 \\
\hline EFCC & 4.7 & 26.0 & 30.7 & 18.4 & 33.0 & 22.6 & 9.0 \\
\hline Fuel Cells & 1.2 & 17.8 & 19.0 & 15.7 & 20.6 & 14.2 & 3.6 \\
\hline ATS & 3.5 & 32.5 & 36.0 & 12.1 & 35.4 & 5.2 & 1.3 \\
\hline $\begin{array}{c}\text { Fuels } \\
\text { Production }\end{array}$ & .9 & 15.1 & 20.9 & 15.5 & 22.0 & 13.8 & 6.0 \\
\hline $\begin{array}{c}\text { Fuels } \\
\text { Processing }\end{array}$ & .9 & 14.0 & 10.0 & 10.0 & 10.7 & 6.0 & 2.9 \\
\hline \begin{tabular}{c} 
EWM \\
\hline $\begin{array}{c}\text { Technology } \\
\text { Mission } \\
\text { Totals }\end{array}$
\end{tabular} & 23.2 & 212.8 & 236.0 & 148.7 & 239.8 & 142.4 & 56.5 \\
\hline
\end{tabular}

\section{Progress/Issues}

Third quarter progress of the Technology Mission has generally been good. Most plans for FY93 achievements appear to remain valid. Performance for the Integrated Gasification Combined Cycle (IGCC) and the Advanced Turbine Systems (ATS) Mission Areas continue to be ahead of expectations. Advances in cleanup technology and progress on Clean Coal Technology projects have helped the IGCC systems Mission Area. Performance in the PFBC Mission Area is being delayed by NEPA issues concerning a major procurement. This delay is likely to contribute to a reduced annual performance score for PFBC.

\section{Highlights}

- A significant risk reduction occurred for second generation IGCC systems when testing of a new sorbent in the cleanup system met all anticipated needs.

- Solid Oxide fuel cell successfully completed 5,000 hour test

- Reservoir modelling of western gas field completed with identification of 5 additional well sites

- METC process development unit design was successfully completed and was selected as a winner of the AIChE innovative process of the year award

- In-house METC research initiated a new project on a novel concept for making ceramic hot filters 
Area level. The first page of the Annual Report is a Summary Table with METC's performance scores and finances for each Mission, followed by two pages that provide brief summary narratives for each Mission. Performance and narrative for each Mission Area is then summarized in a single page.

The total length for the METC Annual report depends on the number of Mission Areas; in this example it would be 15 pages. The external review report would be summarized on the last page. An overview of the layout for a METC annual report to $\mathrm{FE}$ headquarters is shown in Figure 3.2 with a page pulled aside to show the Mission Area format.

Illustrations of the tables that might be used for the first four pages of the METC Annual report are presented on the following four pages.

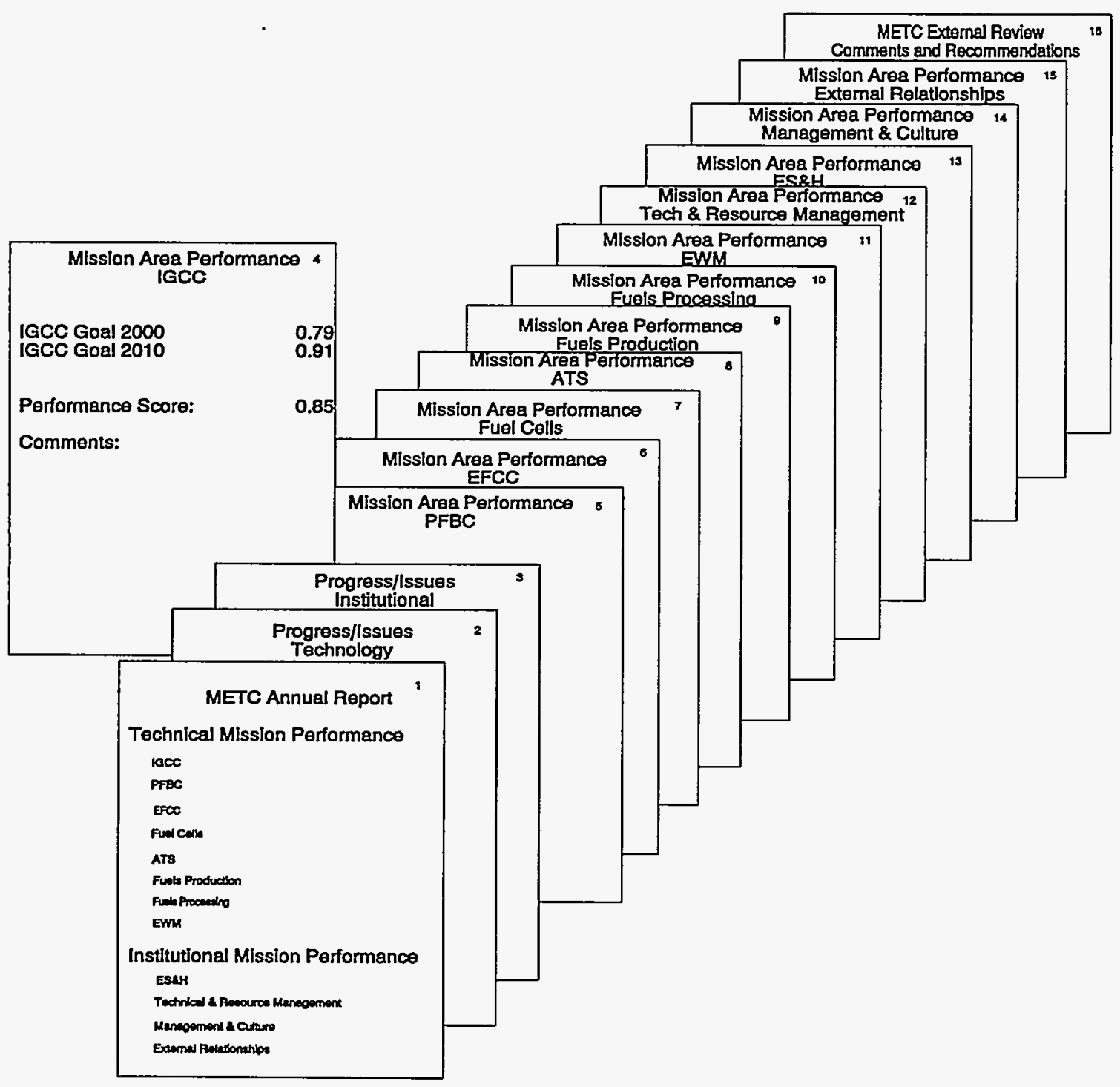

Figure 3.2. Overview of Contents of METC's Annual Report 


\section{Technology Mission Performance}

\begin{tabular}{|c|c|c|c|c|c|c|c|c|}
\hline \multicolumn{3}{|c|}{$\begin{array}{l}\text { Technology Mission Performance } \\
\text { Score= Level } 9\end{array}$} & \multicolumn{3}{|c|}{$\begin{array}{l}\text { Mission is progressing well; minor } \\
\text { corrective work needed. }\end{array}$} & \multicolumn{3}{|c|}{$\begin{array}{c}\text { IGCC, ATS, and EWM Products } \\
\text { have scores } \\
>80 \text {, two are Power Systems, } \\
\text { one is "other". }\end{array}$} \\
\hline $\begin{array}{l}\text { Technology } \\
\text { Mission Area }\end{array}$ & $\begin{array}{l}\text { FY92 } \\
\text { Carryover }\end{array}$ & $\begin{array}{c}\text { FY93 } \\
\text { Budget } \\
\text { Authority }\end{array}$ & $\begin{array}{c}\text { FY93 } \\
\text { Planned } \\
\text { Obligations }\end{array}$ & $\begin{array}{c}\text { FY93 } \\
\text { Actual } \\
\text { Obligations }\end{array}$ & $\begin{array}{l}\text { FY93 } \\
\text { Planned } \\
\text { Costs }\end{array}$ & $\begin{array}{l}\text { FY93 } \\
\text { Actual } \\
\text { Costs }\end{array}$ & $\begin{array}{c}\text { FY93 } \\
\text { Cost } \\
\text { Sharing }\end{array}$ & $\begin{array}{c}\text { Overall } \\
\text { Performance } \\
\text { Score }\end{array}$ \\
\hline IGCC & 2.2 & 42.6 & 44.8 & 42.6 & 44.6 & 45.3 & 11.3 & 85 \\
\hline PFBC & 6.9 & 39.8 & 46.7 & 45.8 & 46.0 & 43.7 & 21.9 & 75 \\
\hline EFCC & 4.7 & 26.0 & 30.7 & 29.8 & 33.0 & 21.1 & 8.4 & 70 \\
\hline Fuel Cells & 1.2 & 17.8 & 19.0 & 18.1 & 20.6 & 19.4 & 4.9 & 75 \\
\hline ATS & 3.5 & 32.5 & 36.0 & 34.6 & 35.4 & 36.0 & 9.0 & 90 \\
\hline $\begin{array}{l}\text { Fuels } \\
\text { Production }\end{array}$ & .9 & 15.1 & 20.9 & 18.0 & 22.0 & 13.0 & 6.0 & 75 \\
\hline $\begin{array}{l}\text { Fuels } \\
\text { Processing }\end{array}$ & .9 & 14.0 & 10.0 & 10.7 & 10.7 & 4.4 & 1.8 & 75 \\
\hline EWM & 2.9 & 25.0 & 27.9 & 25.1 & 27.5 & 26.5 & 13.3 & 91 \\
\hline $\begin{array}{l}\text { Technology } \\
\text { Mission Totals }\end{array}$ & 23.2 & 212.8 & 236.0 & 224.7 & 239.8 & 209.4 & 76.6 & Level 9 \\
\hline
\end{tabular}

\section{Institutional Mission Performance}

\begin{tabular}{|c|c|c|c|c|c|c|c|}
\hline \multicolumn{3}{|c|}{$\begin{array}{l}\text { Institutional Mission Performance } \\
\qquad \text { Score }=\text { Level } 6\end{array}$} & \multicolumn{3}{|c|}{$\begin{array}{l}\text { Slow Mission progress; trends } \\
\text { positive; barriers identified. }\end{array}$} & \multicolumn{2}{|c|}{$\begin{array}{c}\text { KIs in midrange; trends mixed. } \\
\text { TA and CE scores over wide } \\
\text { range. }\end{array}$} \\
\hline $\begin{array}{l}\text { Institutional } \\
\text { Mission Area }\end{array}$ & $\begin{array}{l}\text { FY92 } \\
\text { Carryover }\end{array}$ & $\begin{array}{l}\text { FY93 } \\
\text { Budget } \\
\text { Authority }\end{array}$ & $\begin{array}{c}\text { FY93 } \\
\text { Planned } \\
\text { Obligations }\end{array}$ & $\begin{array}{c}\text { FY93 } \\
\text { Actual } \\
\text { Obligations }\end{array}$ & $\begin{array}{l}\text { FY93 } \\
\text { Planned } \\
\text { Costs }\end{array}$ & $\begin{array}{l}\text { FY93 } \\
\text { Actual } \\
\text { Costs }\end{array}$ & $\begin{array}{l}\text { Overall } \\
\text { Performance } \\
\text { Score }\end{array}$ \\
\hline $\begin{array}{l}\text { Technical and } \\
\text { Resource } \\
\text { Management }\end{array}$ & 0.5 & 5.1 & 5.6 & 5.5 & 5.6 & 5.5 & 59 \\
\hline ES\&H & 2.0 & 4.5 & 6.5 & 6.1 & 6.5 & 5.9 & 66 \\
\hline $\begin{array}{l}\text { Management and } \\
\text { Culture }\end{array}$ & 0.7 & 2.7 & 3.4 & 3.2 & 3.4 & 3.2 & 65 \\
\hline $\begin{array}{l}\text { Extemal } \\
\text { Relationships }\end{array}$ & 0.0 & 0.5 & 0.5 & 0.5 & 0.5 & 0.5 & 61 \\
\hline $\begin{array}{l}\text { Institutional } \\
\text { Mission Totals }\end{array}$ & 3.2 & 12.8 & 16.0 & 15.3 & 16.0 & 15.1 & Level 6 \\
\hline
\end{tabular}




\section{Progress/Issues \\ METC Technology Mission}

[Page 2 of 15]

Narrative:

Progress on the technology Mission has generally been good over Fiscal Year 1993 and all extrapolated commercialization time periods are still valid. The exceptional performance in the Integrated Gasification Combined Cycle (IGCC) and the Advanced Turbine Systems Mission Areas led to the overall Mission score of level 9. Advances in cleanup technology and progress on Clean Coal Technology projects have helped the IGCC systems Mission Area. Restart of the TIDD project and subsequent results from the filter tests have caused a larger risk reduction than expected for IGCC. The PFBC Mission Area was impacted by a less than expected reduction in risk. However, industry interest in this technology is growing, showing acceptance of the technology as performance data become available. The fuel cells Mission Area is proceeding at about three-fourths the planned rate due to difficulties in testing molten carbonate stacks, although a solid oxide landmark test was very successful. The ATS performance is due to a very fast start on this new project area. Participation from utility customers is better than expected; that from the industrial sector is less than hoped. Fuels Production is proceeding satisfactorily although the changes in gas tax incentives have caused some pullback from field development by independent gas producers. The EWM procurements were placed ahead of time and many new and promising ideas are now under contract with tentative field trials already defined for some technologies.

Highlights:

- Sorbents for hot gas cleanup successfully completed 10,000 hours of testing at METC with 100 regenerations and no spalling or degradation

- IGCC Product Plan completed and being implemented

- TIDD Plant successfully completed shakedown and filter tests

- Solid Oxide fuel cell successfully completed 5,000 hour test

- Reservoir modelling of western gas field completed with identification of 5 additional well sites

- METC process development unit design successfully completed and winner of AIChE innovative process of the year award

- Ground-breaking ceremonies held for Gasification Product Improvement Facility

- In-house METC research initiated new project on novel concept for making ceramic hot filters

- Clean Coal V contract negotiations completed with $58 \%$ industrial cost share achieved

- Reduced FY94 appropriations for PFBC required readjustment of milestones from 5-year plan 


\section{Progress/Issues METC Institutional Mission}

Narrative:

Performance for Fiscal Year 1993 ranged from very high for the Technical and Resource Management Mission Area to relatively low for External Relationships, where it is suspected that the measures in the PBIS do not accurately reflect actual progress shown on internal control charts. The ES\&H performance has been adversely affected by resource availability. All Category II actions have been completed and --- , [running briefly through each Mission Area].

Highlights:

- Implementation of Corrective Action Plan ahead of schedule

- Two Upward mobility positions competed in FY93

- METC coordinated regional educational Science Bowl

- Combustion Facility renovation completed

- Overall cost sharing of $29 \%$ achieved in METC procurements

- All METC projects completed first round of SARS reviews

- Contaminated 42-inch fixed-bed gasifier removed from site and contamination remediation successfully completed

- Financial audit indicated no METC issues

- DOE Progress Assessment Team impressed with METC's ES\&H accomplishments

- Formal QA/QC program initiated throughout METC

- METC employees again exceed goals for local CFC drive

- 26 METC employees personally contributed work days to help local needy with chores and home repairs

- Site-wide public address system installed to enhance emergency response capabilities

- Reduced capital FY93 equipment funds prevent replacement of obsolete equipment in METC's laboratories and facilities 


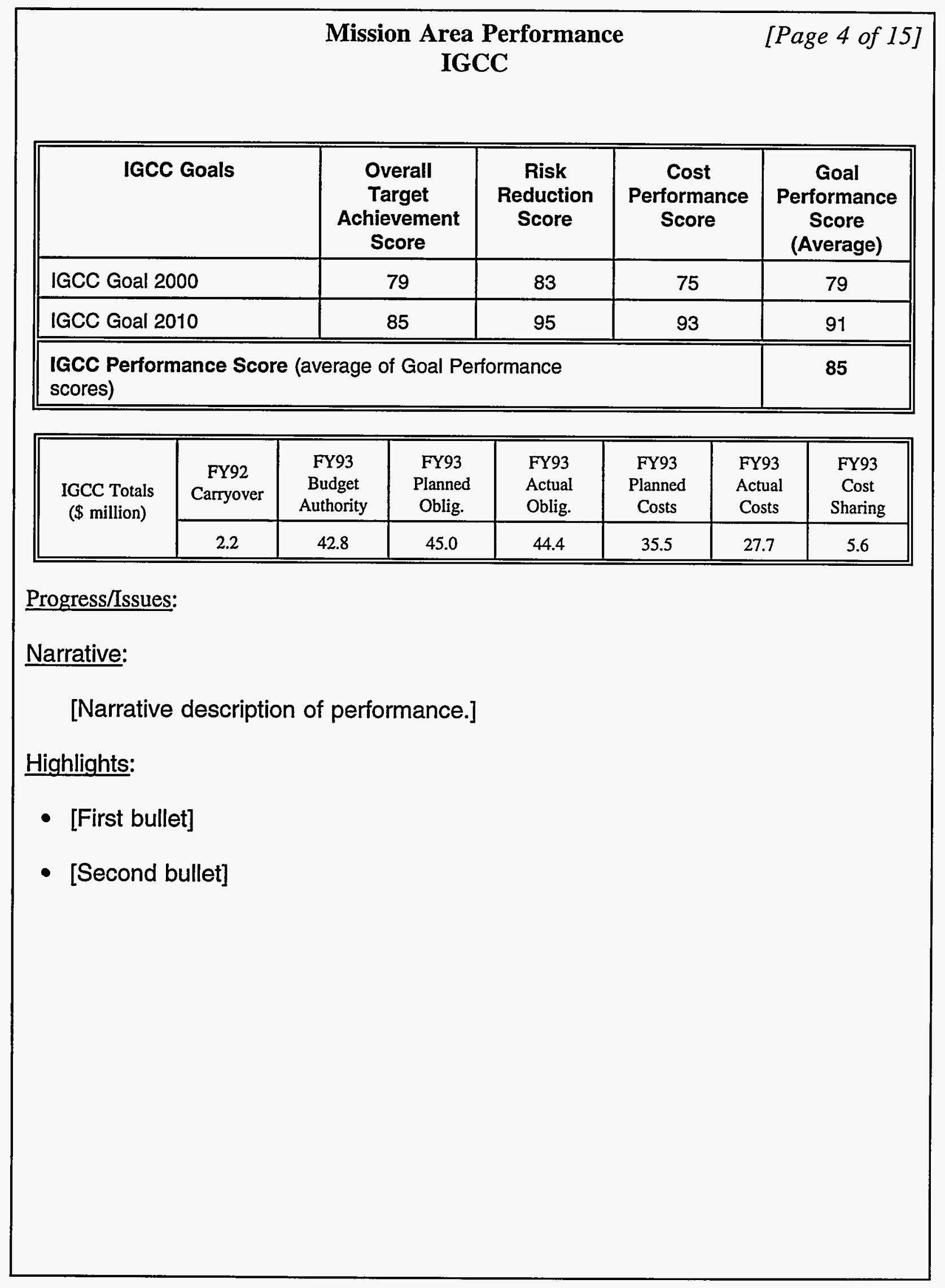




\section{Program Office Report}

The information provided to the headquarters program office is then rolled up and assembled into an Annual report. A mockup of the report is shown in Figure 3.3.

The roll up is done in somewhat the same way as roll ups are made from Mission Area to Missions for the METC example. Summary level performance scores are first compiled for each reporting element of FE; e.g., METC, PETC, BPO, SPR, NPR, Metairie, and Headquarters itself (which has its own functions).

This task is more difficult because the specific measures and scores must be generalized, otherwise readers would have to understand details of the individual PIMMs to understand the report. Consequently, scores must be translated into practical terms. Details of this application are provided in Appendix B.

Once individual performance levels of the organizations are known, the overall Mission performance of FE is evaluated using a PBIS. The PBIS defines the composite scores of the reporting elements necessary to achieve specific levels of overall performance.

An example of a PBIS for the FE Technology Mission is provided in Table 3.1, which uses a bias that METC and PETC, with the major $\mathrm{RD} \& \mathrm{D}$ roles, must both perform well for $\mathrm{FE}$ to have a high-level score. A similar PBIS is used for the FE Institutional Mission and is described in more detail in Appendix B.

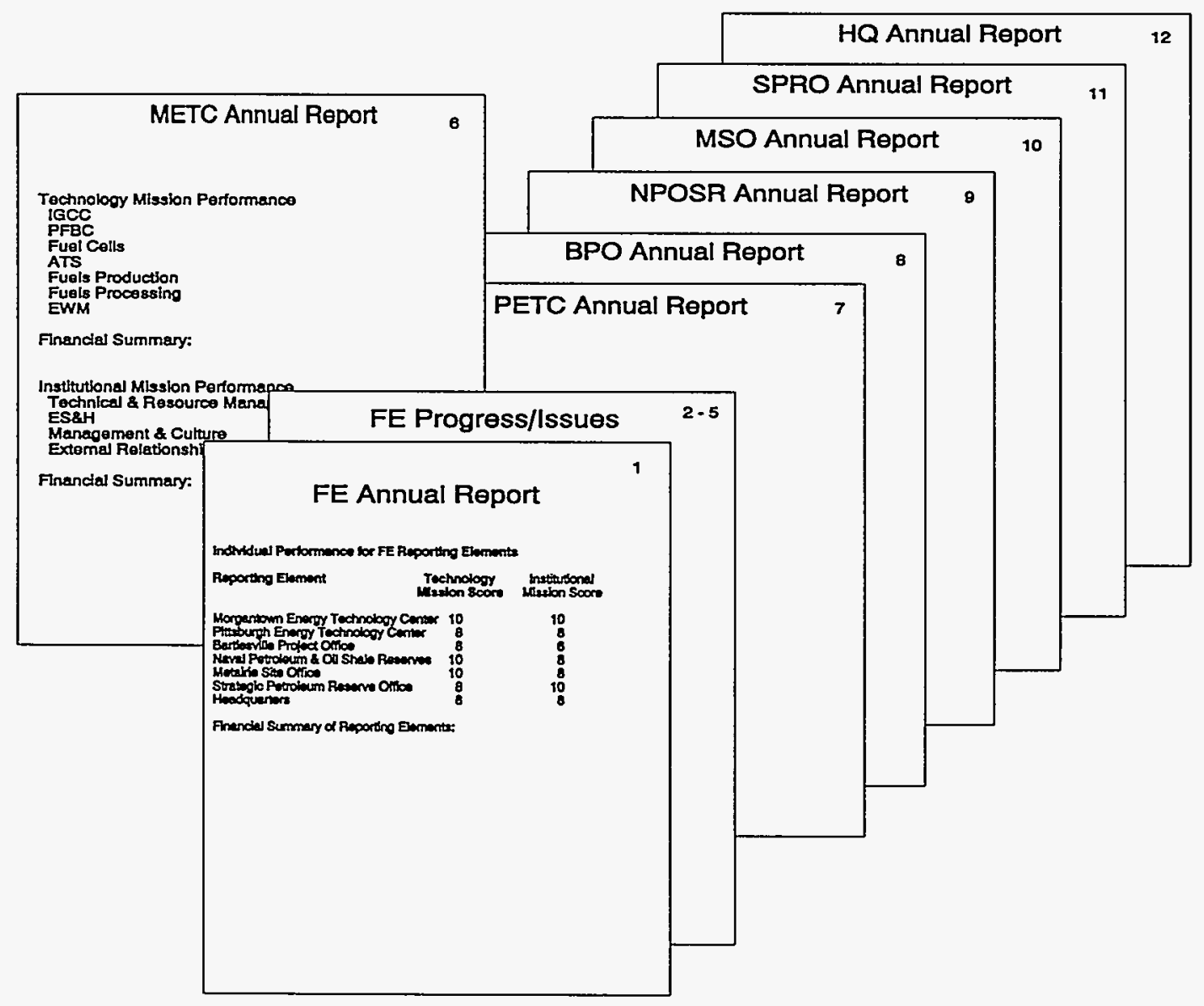

Figure 3.3. Overview of Contents of FE's Annual Report 
Table 3.1. PBIS for the FE Technology Mission

\begin{tabular}{|c|l||}
\hline Level & \multicolumn{1}{c|}{ Description } \\
\hline 10 & $\begin{array}{l}\text { METC \& PETC have Level 10 Performance: At least two other } \\
\text { reporting elements have Level 10 Performance: No reporting element } \\
\text { has less than Level 6 Performance. }\end{array}$ \\
\hline 8 & $\begin{array}{l}\text { METC or PETC has Level 9 Performance and the other has Level } 8 \\
\text { Performance: At least one other reporting element has Level 10 } \\
\text { Performance: No reporting element has less than Level 6 Performance. }\end{array}$ \\
\hline 6 & All reporting elements have at least Level 6 Performance. \\
\hline 4 & One reporting element has less than Level 6 Performance. \\
\hline 2 & More than one reporting element has less than Level 6 Performance. \\
\hline \hline
\end{tabular}

An illustration follows which shows the results of this translation for the first six pages of the FE report to the CFO. The first page is a summary table for FE. The following two pages describe progress/issues for the Technology Mission; the next two pages do the same for the Institutional Mission. The sixth page of the FE report to the CFO is the cover page for METC's report to FE. The seventh is the cover page for the PETC report, and so forth through the page for FE headquarters [plus any appended material]. Using this method, the size of the annual PSO's report can be constrained without extensive rework.

In conclusion, if the PIMM is adopted as a measurement system, compact yet comprehensive performance reporting is possible for both Technology and Institutional Missions. 


\section{FE FY93 Annual Report [Page 1 of 12]}

Individual Performance for FE Reporting Elements

\begin{tabular}{|c|c|c|}
\hline Overall FE Performance & Generic Description & Specific PBIS Description \\
\hline $\begin{array}{c}\text { Technology Mission Performance } \\
\text { Score }=\text { Level } 8\end{array}$ & $\begin{array}{l}\text { Mission progress slowed, } \\
\text { solutions identified. }\end{array}$ & $\begin{array}{l}\text { All reporting elements have at } \\
\text { least Level } 6 \text { Performance }\end{array}$ \\
\hline $\begin{array}{c}\text { Institutional Mission Performance } \\
\text { Score }=\text { Level } 2\end{array}$ & $\begin{array}{l}\text { Mission progress stalled, } \\
\text { major obstacles. }\end{array}$ & $\begin{array}{c}\text { More than one reporting element } \\
\text { has less than Level } 6 \\
\text { Performance. }\end{array}$ \\
\hline Reporting Element & $\begin{array}{l}\text { Technology } \\
\text { Mission Score }\end{array}$ & $\begin{array}{l}\text { Institutional } \\
\text { Mission Score }\end{array}$ \\
\hline Morgantown Energy Technology Center & 9 & 6 \\
\hline Pittsburgh Energy Technology Center & 8 & 6 \\
\hline Bartlesville Project Office & 6 & 2 \\
\hline Naval Petroleum \& Oil Shale Reserves & 10 & 8 \\
\hline Metairie Site Office & 8 & 4 \\
\hline Strategic Petroleum Reserve Office & 8 & 10 \\
\hline Headquarters & 8 & 8 \\
\hline
\end{tabular}

Financial Summary (Millions of dollars)

\begin{tabular}{|c|c|c|c|c|c|c|c|}
\hline $\begin{array}{c}\mathrm{FE} \\
\text { Reporting } \\
\text { Element }\end{array}$ & $\begin{array}{c}\text { FY92 } \\
\text { Carryover }\end{array}$ & $\begin{array}{c}\text { FY93 } \\
\text { Budget } \\
\text { Authority }\end{array}$ & $\begin{array}{c}\text { FY93 } \\
\text { Planned } \\
\text { Obligations }\end{array}$ & $\begin{array}{l}\text { FY93 Actual } \\
\text { Obligations }\end{array}$ & $\begin{array}{l}\text { FY93 } \\
\text { Planned } \\
\text { Costs }\end{array}$ & $\begin{array}{l}\text { FY93 } \\
\text { Actual } \\
\text { Costs }\end{array}$ & $\begin{array}{c}\text { FY93 } \\
\text { Cost } \\
\text { Sharing }\end{array}$ \\
\hline METC & 23.2 & 212.8 & 236.0 & 224.7 & 239.8 & 209.4 & 76.6 \\
\hline PETC & 19.3 & 175.2 & 194.5 & 185.3 & 195.0 & 172.9 & 22.1 \\
\hline BPO & 2.3 & 61.7 & 64.0 & 59.2 & 66.2 & 52.3 & 1.2 \\
\hline NPOSR & 12.6 & 97.6 & 110.2 & 107.1 & 112.3 & 95.4 & - \\
\hline MSO & 1.9 & 42.3 & 44.2 & 43.6 & 45.1 & 39.5 & - \\
\hline SPRO & 32.5 & 290.8 & 323.3 & 308.0 & 351.7 & 256.5 & - \\
\hline HQ & 1.4 & 32.4 & 33.8 & 29.5 & 35.4 & 31.7 & 2.5 \\
\hline $\begin{array}{l}\text { Technology } \\
\text { Mission Totals }\end{array}$ & 93.2 & 912.8 & $1,006.0$ & 957.4 & $1,045.5$ & 857.7 & 102.4 \\
\hline METC & 3.2 & 12.8 & 16.0 & 16.3 & 16.0 & 15.1 & \\
\hline PETC & 5.3 & 15.6 & 20.9 & 17.6 & 20.9 & 20.0 & \\
\hline BPO & 1.1 & 2.4 & 3.5 & 3.3 & 3.5 & 3.3 & \\
\hline NPOSR & 1.2 & 9.8 & 11.0 & 10.7 & 11.0 & 9.8 & \\
\hline MSO & 0.0 & 1.2 & 1.2 & 1.1 & 1.2 & 1.0 & \\
\hline SPRO & 12.2 & 23.5 & 35.7 & 20.5 & 35.7 & 33.4 & \\
\hline $\mathrm{HQ}$ & 0.2 & 7.5 & 7.7 & 6.9 & 7.7 & 7.2 & \\
\hline $\begin{array}{l}\text { Institutional } \\
\text { Mission Totals }\end{array}$ & 23.2 & 72.8 & 96.0 & 75.4 & 96.0 & 89.8 & \\
\hline
\end{tabular}


Narrative:

[Narrative describing FE technology Mission performance]

Progress/Issues

[Page 3 of 12]

FE Technology Mission

Highlights:

[Bullets describing FE technology Mission performance]

Progress/Issues

[Page 4 of 12]

FE Institutional Mission

Narrative:

[Narrative describing FE institutional Mission performance]

Progress/Issues

[Page 5 of 12]

FE Institutional Mission

Highlights:

[Bullets describing FE institutional Mission performance] 


\section{Technology Mission Performance}

\begin{tabular}{|c|c|c|c|c|c|c|c|c|}
\hline \multicolumn{3}{|c|}{$\begin{array}{l}\text { Technology Mission Performance } \\
\text { Score= Level } 8\end{array}$} & \multicolumn{3}{|c|}{$\begin{array}{l}\text { Mission is progressing well; minor } \\
\text { corrective work needed. }\end{array}$} & \multicolumn{3}{|c|}{$\begin{array}{c}\text { IGCC, ATS, and EWM Products } \\
\text { have scores } \\
>80 \text {, two are Power Systems, } \\
\text { one is "other". }\end{array}$} \\
\hline $\begin{array}{l}\text { Technology } \\
\text { Mission Area }\end{array}$ & $\begin{array}{l}\text { FY92 } \\
\text { Carryover }\end{array}$ & $\begin{array}{c}\text { FY93 } \\
\text { Budget } \\
\text { Authority }\end{array}$ & $\begin{array}{c}\text { FY93 } \\
\text { Planned } \\
\text { Obligations }\end{array}$ & $\begin{array}{c}\text { FY93 } \\
\text { Actual } \\
\text { Obligations }\end{array}$ & $\begin{array}{l}\text { FY93 } \\
\text { Planned } \\
\text { Costs }\end{array}$ & $\begin{array}{l}\text { FY93 } \\
\text { Actual } \\
\text { Costs }\end{array}$ & $\begin{array}{c}\text { FY93 } \\
\text { Cost } \\
\text { Sharing }\end{array}$ & $\begin{array}{c}\text { Overall } \\
\text { Performance } \\
\text { Score }\end{array}$ \\
\hline IGCC & 2.2 & 42.6 & 44.8 & 42.6 & 44.6 & 45.3 & 11.3 & 85 \\
\hline PFBC & 6.9 & 39.8 & 46.7 & 45.8 & 46.0 & 43.7 & 21.9 & 75 \\
\hline EFCC & 4.7 & 26.0 & 30.7 & 29.8 & 33.0 & 21.1 & 8.4 & 70 \\
\hline Fuel Cells & 1.2 & 17.8 & 19.0 & 18.1 & 20.6 & 19.4 & 4.9 & 75 \\
\hline ATS & 3.5 & 32.5 & 36.0 & 34.6 & 35.4 & 36.0 & 9.0 & 90 \\
\hline $\begin{array}{l}\text { Fuels } \\
\text { Production }\end{array}$ & .9 & 15.1 & 20.9 & 18.0 & 22.0 & 13.0 & 6.0 & 75 \\
\hline $\begin{array}{l}\text { Fuels } \\
\text { Processing }\end{array}$ & .9 & 14.0 & 10.0 & 10.7 & 10.7 & 4.4 & 1.8 & 75 \\
\hline EWM & 2.9 & 25.0 & 27.9 & 25.1 & 27.5 & 26.5 & 13.3 & 91 \\
\hline $\begin{array}{l}\text { Technology } \\
\text { Mission Totals }\end{array}$ & 23.2 & 212.8 & 236.0 & 224.7 & 239.8 & 209.4 & 76.6 & Level 9 \\
\hline
\end{tabular}

\section{Institutional Mission Performance}

\begin{tabular}{|c|c|c|c|c|c|c|c|}
\hline \multicolumn{3}{|c|}{$\begin{array}{l}\text { Institutional Mission Performance } \\
\qquad \text { Score }=\text { Level } 6\end{array}$} & \multicolumn{3}{|c|}{$\begin{array}{l}\text { Slow Mission progress; trends } \\
\text { positive; barriers identified. }\end{array}$} & \multicolumn{2}{|c|}{$\begin{array}{l}\text { KIs in midrange; trends mixed. } \\
\text { TA and CE scores over wide } \\
\text { range. }\end{array}$} \\
\hline $\begin{array}{l}\text { Institutional } \\
\text { Mission Area }\end{array}$ & $\begin{array}{l}\text { FY92 } \\
\text { Carryover }\end{array}$ & $\begin{array}{l}\text { FY93 } \\
\text { Budget } \\
\text { Authority }\end{array}$ & $\begin{array}{c}\text { FY93 } \\
\text { Planned } \\
\text { Obligations }\end{array}$ & $\begin{array}{c}\text { FY93 } \\
\text { Actual } \\
\text { Obligations }\end{array}$ & $\begin{array}{l}\text { FY93 } \\
\text { Planned } \\
\text { Costs }\end{array}$ & $\begin{array}{l}\text { FY93 } \\
\text { Actual } \\
\text { Costs }\end{array}$ & $\begin{array}{l}\text { Overall } \\
\text { Performance } \\
\text { Score }\end{array}$ \\
\hline $\begin{array}{l}\text { Technical and } \\
\text { Resource } \\
\text { Management }\end{array}$ & 0.5 & 5.1 & 5.6 & 5.5 & 5.6 & 5.5 & 59 \\
\hline ES\&H & 2.0 & 4.5 & 6.5 & 6.1 & 6.5 & 5.9 & 66 \\
\hline $\begin{array}{l}\text { Management and } \\
\text { Culture }\end{array}$ & 0.7 & 2.7 & 3.4 & 3.2 & 3.4 & 3.2 & 65 \\
\hline $\begin{array}{l}\text { Extemal } \\
\text { Relationships }\end{array}$ & 0.0 & 0.5 & 0.5 & 0.5 & 0.5 & 0.5 & 61 \\
\hline $\begin{array}{l}\text { Institutional } \\
\text { Mission Totals }\end{array}$ & 3.2 & 12.8 & 16.0 & 15.3 & 16.0 & 15.1 & Level 6 \\
\hline
\end{tabular}




\section{Implementation Schedule}

METC's implementation of this performance measurement methodology is being initiated in FY94 as a Federal pilot project under the GPRA. The two major efforts involved in PIMM implementation are definition of the infrastructure by which the process is executed and establishment of the data tables used in the scoring process.

The PIMM process is straightforward enough that execution should be possible within normal work assignments once the process is understood and established. Consequently, the initial phase of implementation will involve educating the users.

The organization to be used at METC is depicted in Figure 4.1. An Implementation Team will be responsible for coordination and oversight of the implementation. This team has four major functional blocks. Senior managers are responsible for the Technology and Institutional Missions. Two "contacts" coordinate the implementation with DOE-HQ, and a senior financial expert assists with financial information. The Mission Leaders will appoint individuals to manage PIMM activities for each Mission Area within the two Missions. METC's "product managers" are expected to be responsible for their respective Technology Mission Areas, and key functional managers serve as leaders for Institutional Mission Areas.

The Mission Area leaders in conjunction with the implementation team will establish the Goals, annual Targets, PBIS tables (wherever used), Risk Profiles (for the Technology Mission Areas), and Key Indicators (for the Institutional Mission Areas). The PIMM data tables must be consistent with Strategic Plans, Product Plans, Project Implementation Plans (PIPs), and similar programmatic documents. The Measurements Team identified in Figure 4.1 is the team which generated this PIMM process (Phase I indicates the activity dealing with PIMM). This team will

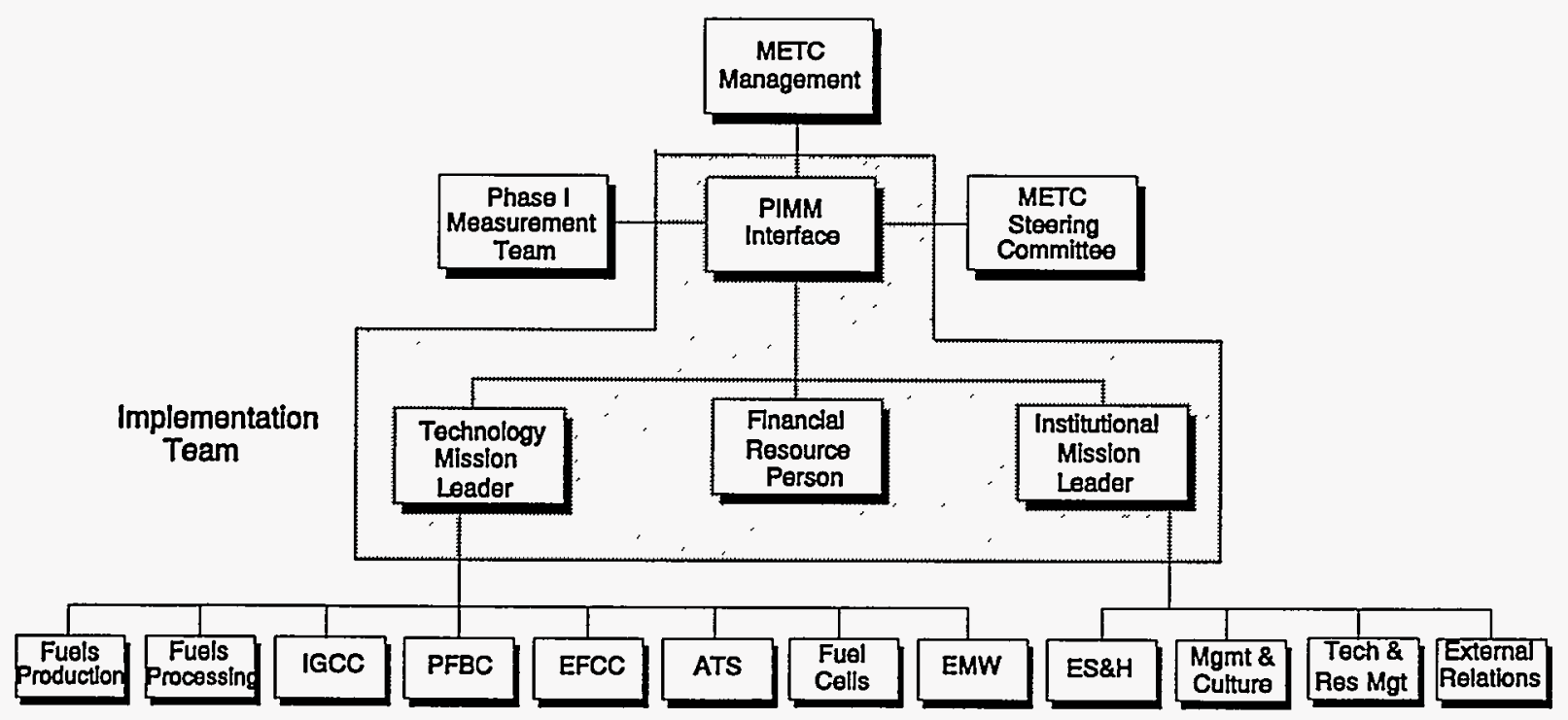

Figure 4.1. METC GPRA Pilot Implementation Structure 
provide training and consultation to the implementation team, and will also provide a level of oversight/guidance to the PIMM process until the implementation team has matured enough to function on its own (at which point the Measurements Team will disband).

Figure 4.2 illustrates the "process flow" of the implementation. The philosophy of the PIMM is to force a focus on the "essential few" outcomes which are key to carrying out a major mission of the organization; for example, the commercialization of technology products. These outcomes are to be reflected and supported by milestones at the Target level in the PIMM - which results in a total of four levels of hierarchy (i.e., viewed from the bottom up as Target, Goal, Mission Area, and Mission levels).

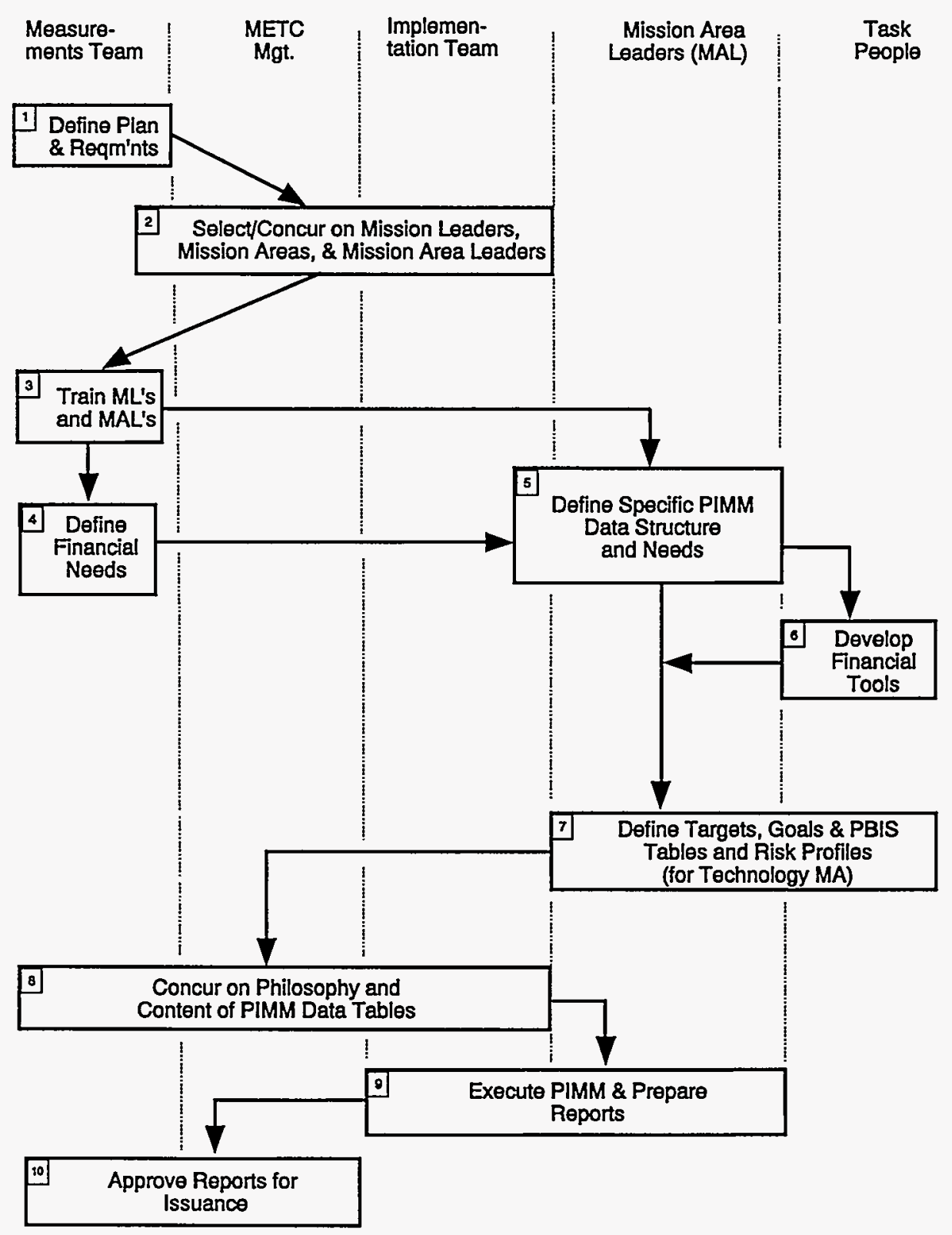

Figure 4.2. Flow Diagram of PIMM Implementation 
Following establishment of Goals and Targets, there is a conceptualization step to define any PBIS tables which are appropriate to the types of activities being measured and may be needed to meld disparate achievements into a "score" (the PBIS concept and examples were presented in Section 2). A similar type of conceptual process, which applies only to the Technology Mission Areas, is the development of the risk profiles for each Technology Mission Area.

Lastly, the key indicators are selected for the Institutional Mission Areas. The next few years' funding requirements also need to be planned. Setting up the PIMM data tables requires some effort. However, once established, these data tables are relatively constant year-to-year. In fact, for well-defined activities, it is likely that only the Target level data tables will be updated annually.

While the functions shown in Figure 4.2 were developed for METC, they may also be representative of a first implementation in other organizations. Four tiers of measurement hierarchy may not always be adequate for internal purposes, and a complex organization may wish to go to sub-Target levels to meaningfully rate its progress. However, excessive detail may obscure the purpose of the PIMM, which is performance measurement and reporting of progress against the major mis$\operatorname{sion}(s)$ of the organization.

PIMM reporting is very straightforward. The quarterly reports consist of only summary-level financial data and some brief text focussing on results at the Mission Area level. The annual reports require the structured performance evaluation of the year's performance using the data tables, plus some very brief results-focused supporting text and an external review report. The reports are produced by the Implementation Team and delivered to senior METC Management for review prior to external reporting.

Some consideration needs to be given to the timing of the PIMM annual report. The annual report is the most comprehensive report and needs to be coordinated with the DOE budget cycle for the "next" year.

In order to include the latest data, it may be necessary for the annual report to be generated at the end of December. However, it is currently planned to begin generating the annual report immediately following the end of the fiscal year.

It is anticipated that the initial version of PIMM data tables will receive only a METC internal review, since the first External Panel will be convened at the beginning of FY95. However, during subsequent years, the data tables and plans for use during the following year will be reviewed and commented on by the External Panel. Table 4.1 provides the planned implementation schedule and a terse description of all the activities.

The draft final report will be sent to an external review panel to prepare for an annual review to be conducted at METC's site in November, 1994. During the review, the panel will assess the internal evaluation of performance for FY94 activities, and the performance plans for FY95. The panel will provide a written report to METC's Director. METC will attach a summary of the panel's report to the final annual report. 
Table 4.1. METC GPRA Pilot Implementation Schedule for FY94

\begin{tabular}{|c|c|}
\hline $\begin{array}{l}\text { Start } \\
\text { Date }\end{array}$ & $\begin{array}{l}\text { Activity } \\
\text { Description }\end{array}$ \\
\hline $3 / 1 / 94$ & Initiate preparation of the Performance Plan to implement the PIMM pilot. \\
\hline $3 / 7 / 94$ & $\begin{array}{l}\text { Launch pilot. Choose Mission Leaders and Mission Area Leaders. } \\
\text { Management and Mission Leaders to concur on the mission Areas and } \\
\text { general content of the Performance Plan. Guidance provided by the } \\
\text { Measurement Team. Oversight Team to train the PIMM Team (the Mission } \\
\text { and Mission Area Leaders). }\end{array}$ \\
\hline $3 / 16 / 94$ & Submit draft Performance Plan to DOE GPRA pilot coordinators officials. \\
\hline $5 / 13 / 94$ & Establish Goals, Key Indicators, and FY94 Targets. \\
\hline $7 / 1 / 94$ & Internal review: interim status of pilot. \\
\hline 9/01/94 & $\begin{array}{l}\text { Complete establishment of baselines for Risk Reduction and key Indicators } \\
\text { for all Technology and Institutional Mission Areas. }\end{array}$ \\
\hline 9/30/94 & End of first annual performance period for METC GPRA pilot. \\
\hline $10 / 8 / 94$ & All inputs provided for the annual report. \\
\hline $10 / 31 / 94$ & Complete draft of annual report for review by External Panel. \\
\hline $11 / 15 / 94$ & Annual External Panel Review of METC Performance. \\
\hline $11 / 30 / 94$ & to DOE GPRA pil \\
\hline
\end{tabular}




\section{Appendix A: Applications to METC Measurements}

This section illustrates the use of the concepts introduced in Section 2 by applying them to METC. The examples are hypothetical using information available in METC documents, so they are realistic to METC's Mission; however, they are presented solely for the purpose of illustrating the methodology. They do not necessarily represent the actual METC results of an application of the PIMM.

\section{Mission Descriptions}

METC has two Missions: a Technology Mission and an Institutional Mission.

The Technology Mission is achieved by RD\&D of energy technologies that promise improved efficiency, environmental performance, and cost; with the eventual outcome of commercialization of those technologies. The Institutional Mission provides the necessary infrastructure to achieve the Technology Mission in an efficient and costeffective way. The METC Mission leads to the statements of the desired outcomes as shown in Table A.1.

\section{Technology Mission Areas}

Mission Areas for the METC technology Mission as earlier outlined in Figure 2.3 are identified in Table A.2 below. METC is structurally and strategically organized to deliver product systems via $\mathrm{RD} \& \mathrm{D}$. These products align under Mission Areas or product lines and

Table A.1. METC Mission Outcomes

\begin{tabular}{||l|l||}
\hline \multicolumn{1}{|c|}{ Technology Mission Outcomes } & \multicolumn{1}{c|}{ Institutional Mission Outcomes } \\
\hline $\begin{array}{l}\text { Successful commercialization of highly } \\
\text { efficient, environmentally superior, fossil } \\
\text { fuel energy systems which result in rational } \\
\text { use of domestic resources and improved } \\
\text { national economy and international } \\
\text { competitiveness. }\end{array}$ & $\begin{array}{l}\text { Federal resources and ES\&H responsibili- } \\
\text { ties are managed in a cost effective, }\end{array}$ \\
quality, and socially responsible manner. \\
\hline
\end{tabular}

Table A.2. METC Technology Mission Areas or Product Lines

\begin{tabular}{|c||}
\hline Integrated Gasification Combined Cycle (IGCC) \\
\hline Pressurized Fluid Bed Combustion (PFBC) \\
\hline Externally Fired Combined Cycles (EFCC) \\
\hline Advanced Turbine Systems (ATS) \\
\hline Utility Fuel Cells \\
\hline Fuels Production (Upstream) \\
\hline Fuels Processing (Downstream) \\
\hline Environment and Waste Management Technologies (EWM) \\
\hline
\end{tabular}


are primarily systems that provide industry with the basis for advanced plants for electric power production or production of fuels that can replace imported oil. An exception is the Environment and Waste Management Product Line which consists of processes and methods to mitigate and manage wastes. Successful completion of one of the Technology Mission Areas is synonymous with the technology going commercial and beginning to achieve market share.

\section{The IGCC Mission Area}

The IGCC Mission Area (product line) consists of two Goals (products) represented by two successive improvements of IGCC technology. Each improvement entails higher system performance, lower costs, earlier stages of RD\&D and thus later commercialization dates. The system performance characteristics may be written as Goal statements as shown in the table below.

\section{Targets for IGCC Goal 2000}

The first Goal of the IGCC system (IGCC Goal 2000) is chosen to illustrate the PIMM methodology for developing annual Targets. For each long range Goal, a set of shorter range Targets is developed which are important milestones and collectively lead to achievement of the Goal. The first year Targets for a new Goal are likely to be similar for all Technology Mission Goals, while later Targets are specific to the technology. Table A.4 shows Targets for two arbitrarily selected years of the first IGCC Goal (IGCC Goal 2000).

\section{Risk Analysis}

Risk analysis is a new aspect of Performance Measurement for RD\&D programs. The objective of Risk Analysis is to develop an estimate of the risk of commercializing the technology of interest. In Section 2, "Risk" was operationally defined as a number that considers the technical challenges and their importance to the success of the technology. The Risk Profile integrates the RD\&D schedule together with the time available to solve the problems underlying the risk.

In a practical sense, the risk analysis is developed by the product manager, or someone else who understands the details of the technology and the customer's requirements, and is reviewed internally as well as by the external

Table A.3. IGCC Mission Area Goals

\begin{tabular}{|c|c|}
\hline IGCC Generation & Goal \\
\hline IGCC Goal 2000 & $\begin{array}{l}\text { By year } 2000 \text {, at least } 1,500 \text { megawatts of cumulative } \\
\text { IGCC capacity will be ordered for delivery by } 2005 \text {, } \\
\text { based on IGCC system with efficiency of } 45 \% \text {, cost of } \\
\$ 1200 / \mathrm{kW} \text {, and environmental emissions } 1 / 10 \text { th of } \\
\text { federal regulations. }\end{array}$ \\
\hline IGCC Goal 2010 & $\begin{array}{l}\text { By year } 2010 \text {, at least } 15,000 \text { megawatts of cumulative } \\
\text { IGCC capacity will be ordered for delivery by } 2012 \text {, } \\
\text { based on IGCC system with efficiency of } 52 \% \text {, cost of } \\
\$ 1050 / \mathrm{kW} \text {, and environmental emissions } 1 / 10 \text { th of } \\
\text { federal regulation. }\end{array}$ \\
\hline
\end{tabular}


Table A.4. Targets for IGCC Goal 2000

\begin{tabular}{||l|l||}
\hline Year & \multicolumn{1}{|c|}{ Targets } \\
\hline \hline \multirow{5}{*}{ First } & $\begin{array}{l}\text { Establish a Product Development plan that addresses potential market } \\
\text { shares for the Product, cost of the technology, major technology, } \\
\text { environmental, economic, and other risks, and investment estimates (public } \\
\text { and private) necessary to commercialize the Product. }\end{array}$ \\
\cline { 2 - 3 } & $\begin{array}{l}\text { Identify system concepts that can achieve the Goals of the Product } \\
\text { development plan; evaluate concepts and identify a primary and a "back } \\
\text { stop" system. }\end{array}$ \\
\cline { 2 - 3 } & Identify key components and technical barriers. \\
\cline { 2 - 3 } & Develop a procurement strategy to support the primary system concept. \\
\cline { 2 - 3 } & Prepare a risk reduction profile for the product development effort. \\
\cline { 2 - 3 } & Establish a "rolling" five-year plan with intermediate Goals. \\
\hline \hline \multirow{5}{*}{ Third } & $\begin{array}{l}\text { Conduct proof-of-concept tests of an advanced hot gas desulfurization } \\
\text { concept. }\end{array}$ \\
\cline { 2 - 3 } & $\begin{array}{l}\text { Use proof-of-concept results to design a demonstration of an advanced hot } \\
\text { gas desulfurization concept. }\end{array}$ \\
\cline { 2 - 3 } & Conduct bench-scale tests of advanced particle removal devices. \\
\cline { 2 - 3 } & Conduct lab-scale tests of hazardous pollutant removal concepts. \\
\cline { 2 - 3 } & Complete CCT demonstration of the IGCC Goal 2000 system. \\
\hline
\end{tabular}

review panel. The result of the risk analysis is a numerical risk estimate for each major subsystem or component of the technology, and a risk estimate for the product as a whole. The risk estimate is not meaningful on an absolute scale, but rather is a measurement of how much risk the technology has relative to a risk that would be acceptable to a company planning immediate commercialization.

The risk analysis used with the RD\&D plans allows the manager to develop a year-by-year Risk Reduction Profile. An example of a Risk Reduction Profile, developed for the Integrated Gasification Combined Cycle (IGCC) Goal 2000 product is shown in Figure A.1. Details of the method to derive the present risk level on the

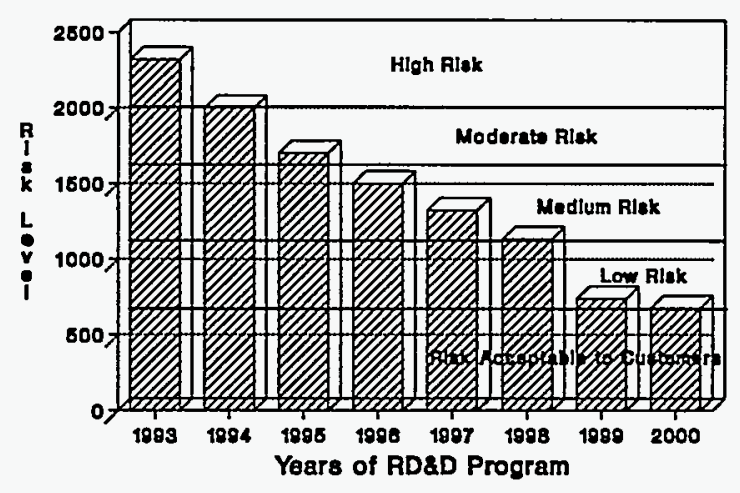

Figure A.1. Planned Risk Reduction Profile Through RD\&D 
vertical scale in the figure are provided in Appendix E. RD\&D should be managed to reduce the overall risk for the product in the minimum time and for the least cost. The premise is that successful $R D \& D$ will reduce the risk to a level acceptable for an introductory commercial product (labelled in the figure as "Risk Acceptable to Customer").

As actual RD\&D proceeds, the risk score will be recalculated. It is also possible to make changes in the $R D \& D$ program that hasten risk reduction in light of the knowledge gained from the risk analysis and RD\&D results. Conversely, a surprising failure or setback could actually raise the risk level. Finally, performance is measured by comparing the actual risk reduction as a percentage of planned risk reduction achieved at any time during the development. By analyzing the technical risks in terms of subsystems, and evaluating the achieved risk reduction, an organization can annually assess its progress on technology development efforts that typically take many years to deliver a final product.

\section{Cost Performance}

Conceptually, Cost Performance is defined here as "what we should pay compared to what we actually pay" for the outcome desired. For each Goal in the Technology Mission, risk reduction is the most important outcome on an annual basis. Therefore, for the Technology Mission, risk reduction is the baseline for Cost Performance. Thus, for these Goals, Cost Performance is evaluated by comparing the planned costs for the actual risk reduction achieved to the actual costs incurred for that same risk reduction. For the Institutional Mission, at the Goal or Mission Area level depending on availability of cost information, a Cost Performance parameter can be calculated by comparing the planned costs incurred to the actual costs for the same achievement level. This kind of evaluation will be presented only in the annual report.

The calculation method can be expressed in a formula as follows:

Cost Performance Score $=\frac{\begin{array}{c}\text { Planned Cost for Actual } \\ \text { Risk Reduction }\end{array}}{\begin{array}{c}\text { Actual Cost for } \\ \text { Actual Risk Reduction }\end{array}} \times 100$

In this example, the formula is applied by the product manager at the Goal level. Procedurally, the product manager first determines the actual risk reduction for each Goal, determines the actual costs for each goal, then consults the Risk Profile to find the planned cost corresponding to the risk reduction attained. This provides the data for the calculation.

\section{Target Performance for IGCC Goal 2000 - Third year of program (1995)}

This illustration assesses progress against the third year Targets for the first IGCC Goal (IGCC Goal 2000), as shown in the bottom half of Table A.4. Table A.5 shows a list of hypothetical Target Achievement scores for the third year Targets, using the Priorities and PBIS outlined in Section 2 (Tables 2.1 and 2.2). Table A.5 also shows a hypothetical Risk Reduction Score (just below the third horizontal double line). For this example, it was assumed that the third year's Risk Reduction Target was almost fully achieved (a score of 90). The Goal Cost Performance score is shown in Table A.5 (bottom line of the table) for the IGCC Goal 2000 example.

Scores for Target Achievement, Risk Reduction, and Cost Performance are merged into an overall performance score by simple averaging. This results in an overall Goal performance score of 79 for the IGCC Goal 2000 example as shown in Table A.6. 
Table A.5. Performance for IGCC Goal 2000, Third Year of Program

\begin{tabular}{|c|c|c|c|c|}
\hline Target & $\begin{array}{l}\text { Target } \\
\text { Priority }\end{array}$ & $\begin{array}{l}\text { Target } \\
\text { Weight }\end{array}$ & $\begin{array}{c}\text { Target } \\
\text { Achievement }\end{array}$ & Points \\
\hline Hot cleanup proof of concept tests & $\mathrm{H}$ & 9 & 100 & 900 \\
\hline Demonstration design & $\mathrm{M}$ & 3 & 50 & 150 \\
\hline Particle removal proof of concept tests & M & 3 & 100 & 300 \\
\hline Lab Hazardous Air Pollutants tests & $\mathrm{H}$ & 9 & 50 & 450 \\
\hline Successful demonstration unit operation & $\mathrm{H}$ & 9 & 90 & 810 \\
\hline Subtọtal & & 33 & & 2610 \\
\hline \multicolumn{4}{|c|}{ Target Achievement Score $=2610 / 33$} & 79 \\
\hline \multicolumn{4}{|c|}{ Goal Risk Reduction Score (from risk analysis) } & 83 \\
\hline \multicolumn{4}{|c|}{ Goal Cost Performance Score (from separate calculation) } & 75 \\
\hline
\end{tabular}

Table A.6. Determination of Mission Area Performance and Cost Performance Scores

\begin{tabular}{||l|c|c|c|c||}
\hline \multicolumn{1}{|c|}{ IGCC Goals } & $\begin{array}{c}\text { Target } \\
\text { Achievement } \\
\text { Score }\end{array}$ & $\begin{array}{c}\text { Risk } \\
\text { Reduction } \\
\text { Score }\end{array}$ & $\begin{array}{c}\text { Cost } \\
\text { Performance } \\
\text { Score }\end{array}$ & $\begin{array}{c}\text { Goal } \\
\text { Performance } \\
\text { Score } \\
\text { (Average) }\end{array}$ \\
\hline Goal 2000 & 79 & 83 & 75 & 79 \\
\hline Goal 2010 & 85 & 95 & 93 & 91 \\
\hline \hline
\end{tabular}

\section{Calculation of IGCC Mission Area Performance}

Since the two Goals of the IGCC Product represent different time frames of commercialization and different efficiency and environmental performance levels, they do not compete with each other directly. As a result, the total IGCC Mission Area performance score is calculated by averaging the two Goal scores as presented in Table A.6.

\section{Calculation of Technology Mission Performance}

To determine Technology Mission performance, we assume that each Technology Mission Area has received a Performance score, as illustrated in Table A.7.

Applying the PBIS system from Table 2.4 for Technology Mission performance to these overall scores, the resulting Technology Mission Performance is at Level 9. 
Table A.7. Determination of Technology Mission Performance

\begin{tabular}{|l|c|}
\hline \multicolumn{1}{|c|}{ Mission Area } & $\begin{array}{c}\text { Mission Area } \\
\text { Performance } \\
\text { Score }\end{array}$ \\
\hline IGCC & 85 \\
\hline PFBC & 75 \\
\hline EFCC & 70 \\
\hline Fuel Cells & 75 \\
\hline ATS & 90 \\
\hline Fuels Production & 75 \\
\hline Fuels Processing & 75 \\
\hline EWM & 91 \\
\hline \hline Technology Mission Performance Score & Level 9 \\
\hline
\end{tabular}

\section{Institutional Mission Areas}

Institutional Mission Areas are fundamentally different from Technology Mission Areas. These differences must be recognized at the outset, as they affect the nature of the performance measurement.

The Technology Mission represents the organization's "reason for being" within the Federal government and the most important "customers" or beneficiaries of the Mission are outside DOE, and in the case of at least METC, often also outside the Federal government. By contrast, the Institutional Mission provides the infrastructure so that the Technology Mission can be carried out in a responsible and proper manner. This is a vital but supporting mission, without which the Technology Mission could not be carried out. The primary "customers" of the Institutional Mission are essentially all within DOE and a large fraction are internal to the organization performing the evaluation, in this case METC. Another way to look at this is that the Technology Mission is driven by the "marketplace" and the Institutional Mission is driven by a combination of established management practices, DOE directives, and laws.

These and other differences between Institutional and Technology Missions have important implications for goalsetting and measurements. Because government management practices are highly regulated, the content of a given Institutional Mission Area has greater long-term constancy than occurs with a given Technology Mission Area, and activity in an Institutional Mission Area usually continues even after a Goal is reached, as long as the underlying Technology Mission is valid. By contrast, if a long range Goal is achieved in the Technology Mission Area, "victory" could be declared and resources diverted to another Mission Area. In the ES\&H Institutional Mission Area, for example, even if the institution achieves a Goal for reduction of ES\&H incidents, the ES\&H function is still needed to keep incidents low and support the mission. Normally in a case such as this a new Goal will be set and resources adjusted accordingly. 
Also, as pointed out in Section 2, Key Indicators developed for one Institutional Mission Area generally do not fit other Mission areas. The concept of an annually progressive Risk Reduction, which was developed for the Technology Mission Areas, generally does not make sense for the Institutional Mission Areas (there is one exception for the ES\&H area, as explained below). The degree of Target achievement and the relating cost performance are still valid overall measures used to score the Institutional Mission Areas.

The distinctions between the Technology and Institutional Mission Areas for an RD\&D organization such as METC are relatively easy to see; however, this may not be the case for all organizations. Some organizations may have nearly all of their activities devoted to an Institutional Mission, with little or no Technology Mission. The reverse is certainly also possible, e.g., the DOE Metairie Site Office (MSO) obtains virtually all its institutional support from other entities.

\section{Key Indicator Concept}

Key Indicators provide a way to characterize success of each Mission Area that is independent of the Target Achievement and Cost Performance measurements, and is more reflective of how close the institution is to attaining the long range Goals of the Mission Area. The following list provides an operational definition of the Key Indicator concept as used here.

\section{Characteristics of Key Indicators for Insti- tutional Mission}

- "Key indicators" are high level measurements that relate closely to long range goal achievement. Long range in this context may be on the order of five years.

- Trends of these key indicators are directly related to mission success.
- These key indicators are considered in addition to Target Achievement and Cost Performance.

- Key indicators will be "benchmarked"- i.e., there should be a way to compare the indicators with the performance of "the best" outside organizations, both within and without government.

Each of the Institutional Mission Areas (i.e., Technical and Resource Management, ES\&H, Management and Culture, and External Relationships) has a greater degree of uniqueness than occurs among the Technology Mission Areas. The types of issues dealt with, the particular skills utilized, the identity of the external (and internal) customers, and the METC relationships impacted are all quite different for each Mission Area. For this reason, a single Key Indicator cannot be used for all areas, and the Key Indicators must be "customized" for each Mission Area. For the Technology Mission, the risk concept is used as a Key Indicator for all Mission Areas.

As a result, each Institutional Mission Area will have one or several Key Indicators that measure the overall "health" of the Mission Area. A good example of this is the use of the Presidential Award for Quality Criteria (similar to the Baldridge Award Criteria for the private sector) to judge the overall health of the Management and Culture Mission Area.

Figure A.2 illustrates the desired trends for a generic Key Indicator.

In the following sections, the Institutional Mission hierarchy for METC is developed and hypothetical examples of measurements are used to illustrate the methodology. The Mission Areas are described, and examples are given of Goals and Key Indicators for each Mission Area. Hypothetical Targets are developed and used to show the calculation and roll up methodology. 


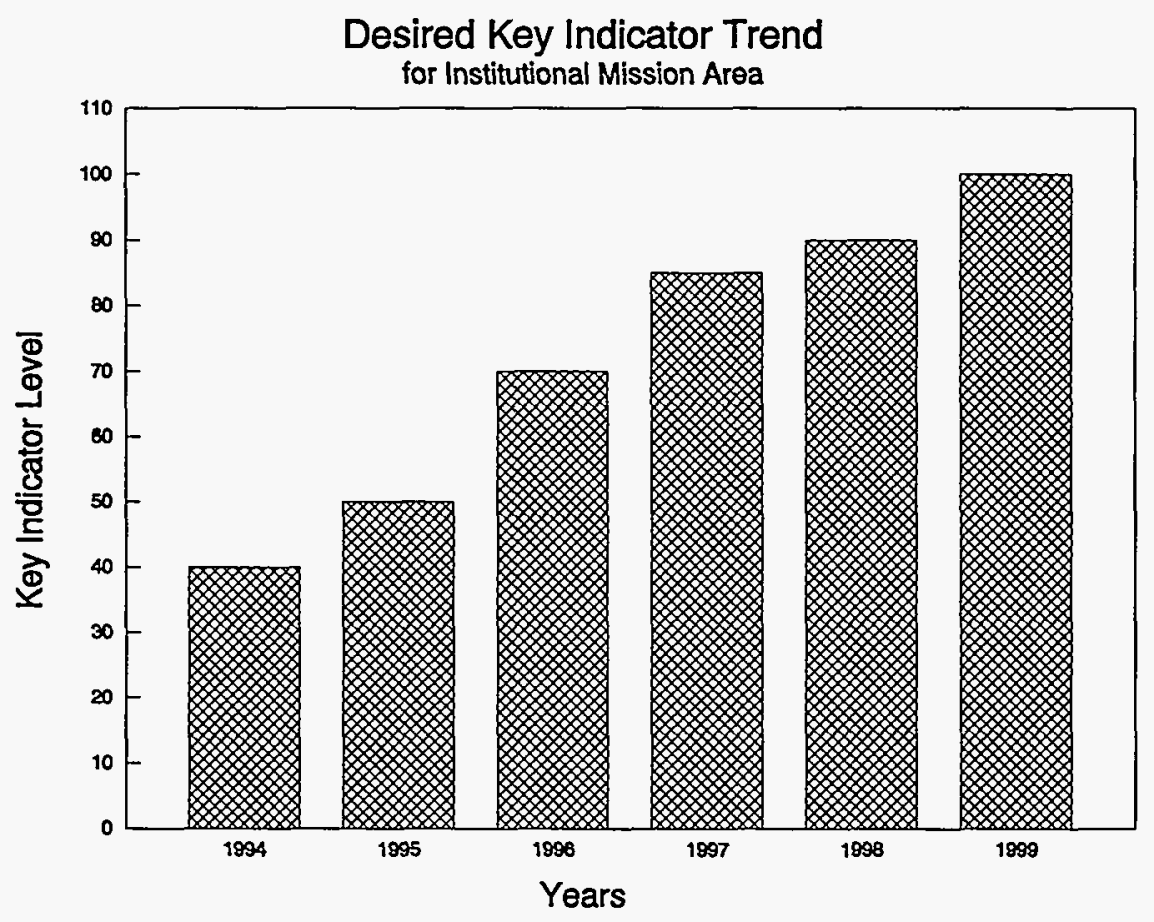

Figure A.2. Example of a Key Indicator Trend

Since the ES\&H Mission Area is somewhat different from the others in its use of the risk concept, for clarity ES\&H as well as another Mission Area are expanded to the Target level.

Table A.8 outlines the Mission Area and Goals hierarchy for METC's Institutional Mission, and lists Key Indicators as well as some potential Benchmarks for the Key Indicators. The Mission Areas shown for METC are likely to be correct, at least for FY94, but the Goals and Targets should be regarded as hypothetical examples and subject to change.

\section{Environment, Safety, and Health (ES\&H) Mission Area}

ES\&H is singled out as a Mission Area because of: (1) its importance in ensuring public confidence and employee trust in METC's actions, and (2) its visibility and separate funding status within DOE. Goals of the ES\&H area represent the outcomes of reduced risk to the public and to METC's population, "culture" change to recognize that ES\&H excellence is an inherent requirement for all programs, and full compliance with regulatory and legal requirements. These goals are achieved through effective planning and implementation, skills and awareness training, self assessments and reviews, monitoring, and documentation and information systems.

\section{A Different Form of Risk Analysis}

One uniqueness of the ES\&H Institutional Mission Area is that it is the only Institutional Mission Area that does at least in part lend itself to the use of a form of "risk" reduction.

The general definition of "risk" within the ES\&H area is the product of the likelihood of an occurrence and the severity of the occurrence's consequences. Occurrences could include release of pollutants or accidents involving workers. Consequences could include 
Table A.8. Institutional Mission, Mission Areas, Goals, and Key Indicators

\begin{tabular}{|c|c|c|c|}
\hline \multicolumn{4}{|c|}{ Institutional Mission - Provide the infrastructure to achieve the Technology Mission in an efficient and cost-effective way } \\
\hline Mission Area & Goals for Mission Area & Key Indicators for Goal & Benchmark for Key Indicator \\
\hline \multirow[t]{3}{*}{$\begin{array}{l}\text { Environment, Safety, \& } \\
\text { Health (ES\&H) }\end{array}$} & $\begin{array}{l}\text { 1. "Risks" are minimized cost } \\
\text { effectively by development and } \\
\text { implementation of plans. }\end{array}$ & $\begin{array}{l}\text { Risk Analysis score using DOE } \\
\text { RPM methodology. }\end{array}$ & $\begin{array}{l}\text { Achieve "low" level, as defined by } \\
\text { RPM methodology, within five years. }\end{array}$ \\
\hline & $\begin{array}{l}\text { 2. All needed ES\&H skills are } \\
\text { developed and METC's ES\&H "cul- } \\
\text { ture" shows continuous improve- } \\
\text { ment. }\end{array}$ & Results of ES\&H culture survey. & $\begin{array}{l}\text { Trends show improvement to positive } \\
\text { culture within five years. }\end{array}$ \\
\hline & $\begin{array}{l}\text { 3. The NEPA and SARS processes } \\
\text { function effectively and all needed } \\
\text { external reporting requirements are } \\
\text { met. }\end{array}$ & $\begin{array}{l}\text { Level of "defects" such as viola- } \\
\text { tions, releases, and occurrences. }\end{array}$ & Improving trends to low levels. \\
\hline \multirow[t]{2}{*}{$\begin{array}{l}\text { Management and } \\
\text { Culture }\end{array}$} & $\begin{array}{l}\text { 1. Achieve and maintain "Master" } \\
\text { status in Total Quality Management }\end{array}$ & $\begin{array}{l}\text { Presidential Award for Quality } \\
\text { (PAQ) criteria score on annual } \\
\text { assessment. }\end{array}$ & $\begin{array}{l}\text { A score exceeding } 800 \text { within five } \\
\text { years. }\end{array}$ \\
\hline & $\begin{array}{l}\text { 2. Management effectiveness equal } \\
\text { to "best in government". }\end{array}$ & $\begin{array}{l}\text { Management effectiveness } 360^{\circ} \\
\text { survey. }\end{array}$ & $\begin{array}{l}\text { Greater than } 95 \% \text { effectiveness in five } \\
\text { years. }\end{array}$ \\
\hline \multirow[t]{4}{*}{$\begin{array}{l}\text { Technical and Resource } \\
\text { Management }\end{array}$} & $\begin{array}{l}\text { 1. Administrative support effective- } \\
\text { ness equal to "best in government". }\end{array}$ & $\begin{array}{l}\text { Level of "internal customer" } \\
\text { satisfaction on administrative } \\
\text { support survey. } \\
\text { Level of improvement of "key" } \\
\text { administrative processes. } \\
\end{array}$ & 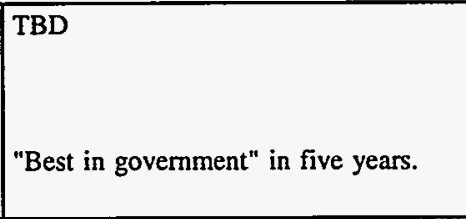 \\
\hline & $\begin{array}{l}\text { 2. Top quality facilities to match } \\
\text { evolving missions and dynamic } \\
\text { workforce. }\end{array}$ & $\begin{array}{l}\text { Level of "internal customer" } \\
\text { satisfaction on facilities survey. }\end{array}$ & TBD \\
\hline & $\begin{array}{l}\text { 3. Flexible and effective workforce } \\
\text { capable of achieving evolving } \\
\text { mission. }\end{array}$ & $\begin{array}{l}\text { Capability indicated by staffing } \\
\text { analysis, such as number of } \\
\text { employee certifications. } \\
\text { Diversity level indicated by } \\
\text { annual statistics. }\end{array}$ & "High" level in five years. \\
\hline & $\begin{array}{l}\text { 4. Continuous improvement in } \\
\text { productivity as reflected by } \\
\text { reduction in overhead costs. }\end{array}$ & $\begin{array}{l}\text { Ratio of "overhead" costs to } \\
\text { total program costs. }\end{array}$ & "Best in government" in five years. \\
\hline External Relationships & $\begin{array}{l}\text { 1. Wide recognition of METC's } \\
\text { integrated model of tech product } \\
\text { development and management, and } \\
\text { public/community acceptance. }\end{array}$ & $\begin{array}{l}\text { Level of customer satisfaction } \\
\text { indicated by stakeholder surveys } \\
\text { and/or feedback- Industry, } \\
\text { Partners, and Public/neighbors. } \\
\text { Scope of mission as indicated by } \\
\text { level of "new business" } \\
\text { Adequacy of budgets. }\end{array}$ & $\begin{array}{l}100 \% \text { increase in "new business" in } \\
\text { five years. } \\
\text { Budgets are adequate to achieve } \\
\text { mission. }\end{array}$ \\
\hline
\end{tabular}

harm to a person, a facility, or the environment, or legal consequences (e.g., law suits) relating to not complying with a related ES\&H requirement. Using this definition, a numerical risk level can be associated with doing nothing new (maintenance of the status quo) and compared to the risk level that would result from implementing some overt ES\&H improvement. This then allows determination of a risk reduction score for the overt ES\&H activity, and it allows managers to rank alternative activities based on their relative risk reductions and costs.

The DOE uses a standardized Risk Prioritization Model (RPM) (see the USDOE Safety and Health Five-Year Plan Assistance Manual dated 
November 1992 for details) as part of the DOE 5-Year ES\&H Planning Process and it is planned to utilize the RPM as a basis for calculating ES\&H risk levels for this measurement effort. The RPM considers consequences or impacts to public safety and health, site personnel safety and environmental protection. The RPM risk evaluator estimates the credible consequences of an "occurrence" at the site and then grossly categorizes the likelihood of the occurrence as very high, high, medium, or low. The categories are:

Very High = Likely to occur about annually High $=$ Likely to occur once every 7-10 years Medium = Likely to occur once in 40-50 years Low $=$ Likely to occur once in 300 years

The RPM process has an established impact (consequence)/likelihood matrix that provides a numerical score for each cell in the matrix which then allows the development of an overall facility "risk score" at a point in time. While the value has little physical meaning, the change in the numerical value provides a rational (and recognized) means of trending ES\&H risk. This process is exercised annually to prepare inputs for the ES\&H 5-Year Plan. Thus, this activity will support the PIMM measurement process without additional work.

The expectation is that overall ES\&H risk progressively decreases with time due to the site's ES\&H improvements. However, it is important to recognize that the perceived ES\&H risk level associated with a facility can legitimately increase for reasons beyond the control of the facility (i.e., not related to deterioration of the physical site or the facility's ES\&H programs). Each year more is learned about the hazards associated with our technologies and sometimes compliance requirements change, and either/both of these can engender new risks. These risks must then be assessed and managed. While a risk profile decreasing with time is expected, step increases which result from new requirements would not be surprising (and should be explained whenever they occur).

\section{Performance Calculation}

To perform the evaluation of the ES\&H Mission Area, the current status of ES\&H accomplishments and the associated costs would be compared to the previous year's plans and Target definitions. A Target Achievement table is then prepared in a manner similar to that used for the Technology Targets. An example for ES\&H Goal 1 could look like the following (Table A.9).

It is assumed that all of the ES\&H Goals are equally important, and then the Target Achievement scores may be numerically averaged to obtain ES\&H Mission Area scores for Target Achievement. This is reflected in Table A.10.

Key Indicator scores are tabulated at the Mission Area level and are shown in Table A.11.

Cost Performance is also determined at the Mission Area level, and is defined for the ES\&H area as "the planned cost corresponding to the amount of actual ES\&H risk reduction divided by the actual cost for the same risk reduction".

In summary, for the ES\&H Mission Area the Mission Area scores are:

Target Achievement score $=78$

Key Indicator score $=26$

Cost Performance score $=95$

\section{Management and Culture Mission Area}

This Mission Area encompasses Total Quality Management as an overarching strategy to achieve high levels of customer satisfaction, workforce motivation, a "can do" culture, and strategic leadership. It also includes "getting things done" by management. 
Table A.9. Target Achievement for ES\&H Goal 1 - Risk Minimization

\begin{tabular}{||l|c|c|c||}
\hline \multicolumn{1}{|c|}{ Target Definition } & $\begin{array}{l}\text { Target } \\
\text { Weight }\end{array}$ & $\begin{array}{c}\text { Target } \\
\text { Achievement }\end{array}$ & Points \\
\hline $\begin{array}{l}\text { Trend all significant ES\&H Incidents and identify } \\
\text { causes }\end{array}$ & 9 & 100 & 900 \\
\hline $\begin{array}{l}\text { Define/prioritize risk reduction projects for next } \\
\text { year }\end{array}$ & 3 & 70 & 210 \\
\hline $\begin{array}{l}\text { Compare achieved risk reduction to last year's } \\
\text { prediction }\end{array}$ & 9 & 80 & 720 \\
\hline Update Corrective Action Plan & 3 & 50 & 150 \\
\hline \hline \multicolumn{1}{|c|}{ Subtotals } & 24 & & 1980 \\
\hline Target Achievement Score (1980/24) & & & 83 \\
\hline
\end{tabular}

Table A.10. Calculation of Mission Area Scores for ES\&H

\begin{tabular}{||l|c|}
\hline \multicolumn{1}{|c|}{ ES\&H Goal } & $\begin{array}{l}\text { Target } \\
\text { Achievement }\end{array}$ \\
\hline \hline Risk Minimization & 83 \\
\hline Skills and Culture & 62 \\
\hline $\begin{array}{l}\text { Compliance and } \\
\text { reporting }\end{array}$ & 90 \\
\hline \hline $\begin{array}{l}\text { ES\&H Mission Area } \\
\text { Target Achievement score }\end{array}$ & 78 \\
\hline
\end{tabular}

The first Goal of the Management and Culture Mission Area is used as an example to illustrate the scoring methodology. This Goal, as listed in Table A.8, is to Achieve and maintain "Master" status in Total Quality Management, where "Master" status is defined as being in the top range of the Presidential Award for Quality criteria (The PAQ is the federal agency equivalent of the Baldridge Award for quality in private enterprise). The Key indicator and Benchmark for this Goal are as follows.
- Key Indicator - Score on annual assessment against the Presidential Award for Quality (PAQ) Criteria.

- Benchmark - PAQ score within five years in the top range, 800 or above, indicating "Master" level of TQM.

The PAQ score is determined by conducting a self assessment on each of the seven major categories of the PAQ criteria. The categories are: Leadership, Information and Analysis, Strategic Quality Planning, Human Resource Development and Management, Management of Process Quality, Quality and Operational Results, and Customer Focus and Satisfaction.

\section{Performance Calculation}

To perform the actual measurements, the Goal must be expanded to show the annual Targets and the achievement for each. Table A.12 is an example of the Goal-level roll up of Target Achievement results for Year 1.

Once Goal-level achievement scores are determined, they are then rolled up to the Mission Area level in Table A.13. 
Table A.11. Key Indicator Scores for the ES\&H Mission Area

\begin{tabular}{||l|c|c|c|c||}
\hline Key Indicator & Raw Score = A & Benchmark = B & Formula & $\begin{array}{l}\text { "Normalized" } \\
\text { score (percent) }\end{array}$ \\
\hline \hline $\begin{array}{l}\text { RPM Risk Analysis } \\
\text { overall score }\end{array}$ & 4000 & 100 & B/A *100 & 2.5 \\
\hline ES\&H Culture survey & 200 & 400 & $\mathrm{~A} / \mathrm{B} * 100$ & 50 \\
\hline $\begin{array}{l}\text { ES\&H "Defects" } \\
\text { (Violations, Incidents } \\
\text { and Occurrences) }\end{array}$ & 20 & 5 & $\mathrm{~B} / \mathrm{A} * 100$ & 25 \\
\hline \hline $\begin{array}{l}\text { Overall Key Indicator } \\
\text { Score for ES\&H } \\
\text { (average) }\end{array}$ & & & & 26 \\
\hline
\end{tabular}

Table A.12. Target Achievement for Year 1 for Goal "Achieve and Maintain 'Master' Status in TQM"

\begin{tabular}{||l|c|c|c||}
\hline \hline Target Definition & $\begin{array}{l}\text { Target } \\
\text { Weight }\end{array}$ & $\begin{array}{l}\text { Target } \\
\text { Achievement }\end{array}$ & Points \\
\hline \hline $\begin{array}{l}\text { Implement annual President's Award for Quality } \\
\text { assessment and establish baseline }\end{array}$ & 9 & 100 & 900 \\
\hline Complete second phase of Strategic Planning process & 9 & 96 & 864 \\
\hline Implement Quality Leadership Survey & 9 & 96 & 864 \\
\hline Implement Quality Leadership training & 9 & 100 & 900 \\
\hline \hline Subtotals & 36 & & 3528 \\
\hline Target Achievement Score & & & 98 \\
\hline
\end{tabular}

Once Target Achievements are compiled and used to calculate the Goal-level and Mission Area-level Achievement Score as shown above, the next step is to determine the Key Indicator scores in the Management and Culture Mission Area. An example is provided for Goal 1, using the Presidential Award for Quality criteria, by rolling up scores for each category of the PAQ criteria. (Normally, details of how Key Indicators are calculated would not be provided in annual reports. An exception is made here because the PAQ criteria are likely to be familiar to readers.) Scoring is done by a sequence of Self Assessment and validation by an outside expert, and example results are shown in Table A.14.

Example scores for the two Key Indicators in this Mission Area are compiled and averaged in Table A.15. 
Table A.13. Calculation of Management and Culture Mission Area Target Achievement Scores

\begin{tabular}{||c|c|}
\hline \multicolumn{1}{|c|}{ Goal } & $\begin{array}{l}\text { Target } \\
\text { Achievement }\end{array}$ \\
\hline \hline "Master status in TQM" & 98 \\
\hline $\begin{array}{l}\text { Management Effective- } \\
\text { ness equal to "best in } \\
\text { government" }\end{array}$ & 92 \\
\hline \hline Mission Area score & 95 \\
\hline
\end{tabular}

Cost Performance is not calculated for this Mission Area because costs are not tracked separately for this category.

In summary, then, Mission Area scores for the Management and Culture Mission Area are as follows:

Target Achievement Score $=95$

Key Indicator Score $=35$

\section{Technical and Resource Management Mission Area}

The Goals and Key Indicators for this Mission Area are listed in Table A.8. This represents one of the largest Institutional Mission Areas both in terms of resources committed and the number of Goals involved. Targets are established for each Goal, scores established at Target level, and Target Achievement scores rolled up to the Goal and Mission Area levels as above for the ES\&H and Management and Culture Mission Areas. Key Indicator scores are compiled by surveys, team analyses using PBISs, or other objective evaluation processes. Key Indicator scores are then averaged to give an overall Mission Area Key Indicator score. Cost Performance for this category is determined at the Mission Area level by multiplying the Mission Area level Target Achievement Score by the planned cost for the year, then dividing by the actual expenditures for the Mission Area for the year.

Table A.14. Determination of Key Indicator Score for the Management and Culture Mission Area Using Presidential Award for Quality Criteria

\begin{tabular}{||l|l|l|l||}
\hline Category of PAQ & $\begin{array}{l}\text { Score }= \\
\text { Percent of } \\
\text { maximum }\end{array}$ & $\begin{array}{l}\text { Maximum } \\
\text { points for } \\
\text { category }\end{array}$ & Category score \\
\hline \hline Leadership & 30 & 125 & 37.5 \\
\hline Information and Analysis & 40 & 75 & 30 \\
\hline Strategic Quality Planning & 60 & 60 & 36 \\
\hline $\begin{array}{l}\text { Human Resource Development and } \\
\text { Management }\end{array}$ & 50 & 170 & 85 \\
\hline Management of Process Quality & 25 & 140 & 35 \\
\hline Quality and Operational Results & 30 & 180 & 54 \\
\hline Customer Focus and Satisfaction & 50 & 250 & 125 \\
\hline \hline PAQ Score = Total of category scores & & 402 \\
\hline
\end{tabular}


Table A.15. Key Indicators for Management and Culture Mission Area

\begin{tabular}{||l|l|l||}
\hline \hline Key Indicator & $\begin{array}{l}\text { Score }= \\
\text { Percent of } \\
\text { maximum }\end{array}$ & $\begin{array}{l}\text { Benchmark } \\
\text { (percent) }\end{array}$ \\
\hline \hline Presidential Award for Quality score & 40 & 80 \\
\hline Management Effectiveness $360^{\circ}$ Survey & 30 & 80 \\
\hline \hline Overall Score (average) & 35 & \\
\hline
\end{tabular}

\section{External Relationships Mission Area}

Goals and Key Indicators for the External Relationships Mission Area are listed in Table A.8. Target Achievement and Key Indicator scores are compiled and rolled up as described above for the Technical and Resource Management Mission area. Key Indicators in this area rely heavily on stakeholder surveys of customers, neighbors, and others; customer satisfaction will have a major influence on the results in this area. Since this Mission Area has only one Goal, the Goal-level Target Achievement score is equal to the Mission Area Target Achievement score. Cost Performance is not determined for this Mission Area because costs are not tracked separately for this category.

\section{Rollup to Institutional Mission Level}

Once Key Indicator and Achievement Scores are compiled for each Mission Area, a Performance Based Indicator System (PBIS) is used to "roll up" the performance scores to the overall Institutional Mission. The PBIS used for this is shown in Table A.16.

\section{Reporting}

A METC Annual Report for the Institutional Mission would look something like Table A.17. 
Table A.16. Performance Based Indicator System for Institutional Mission

\begin{tabular}{||l|l|l||}
\hline Level & Generic PBIS & METC Specific PBIS \\
\hline 10 & $\begin{array}{l}\text { Key indicators and trends are all strongly positive, } \\
\text { show excellent progress toward fulfilling Mission. } \\
\text { Achievement and Cost Performance scores are in } \\
\text { the 90+ range }\end{array}$ & $\begin{array}{l}\text { Key indicators are equal to or better than } \\
\text { benchmarks. Trends are all strongly positive. } \\
\text { Achievement and Cost Performance scores are in } \\
\text { the 90+ range. }\end{array}$ \\
\hline 8 & $\begin{array}{l}\text { Key indicators and trends are all positive, show } \\
\text { Mission is progressing well; minor corrective work } \\
\text { needed. Achievement and Cost Performance } \\
\text { scores are in the 70-89 range. }\end{array}$ & $\begin{array}{l}\text { Key indicators are all near benchmarks. Trends } \\
\text { are all positive. Achievement and Cost Perfor- } \\
\text { mance scores are in the 70-89 range. }\end{array}$ \\
\hline 6 & $\begin{array}{l}\text { Key indicators and trends are mostly positive, but } \\
\text { show slow Mission progress; potential barriers and } \\
\text { solutions are clearly identified. Achievement and } \\
\text { Cost Performance scores are in the 50-69 range. }\end{array}$ & $\begin{array}{l}\text { Some key indicators are close to benchmarks, } \\
\text { others in midrange. Trends are mixed. Achieve- } \\
\text { ment and Cost Performance scores are in the 50- } \\
69 \text { range. }\end{array}$ \\
\hline 4 & $\begin{array}{l}\text { Key indicators are mostly low and trends are more } \\
\text { negative than positive, show that Mission progress } \\
\text { is significantly slowed; solutions unclear. } \\
\text { Achievement and Cost Performance scores are in } \\
\text { the 30-49 range. }\end{array}$ & $\begin{array}{l}\text { Key indicators are mostly below benchmarks, } \\
\text { some in midrange, some in lower range. Trends } \\
\text { are mostly negative. Achievement and Cost Per- } \\
\text { formance scores are in the 30-49 range. }\end{array}$ \\
\hline 2 & $\begin{array}{l}\text { Key indicators are low, trends are all negative and } \\
\text { show Mission stalled; no evident solutions. } \\
\text { Achievement and Cost Performance scores are in } \\
\text { the 10-29 range. }\end{array}$ & $\begin{array}{l}\text { Key indicators are in low ranges. Trends are all } \\
\text { negative. Achievement and Cost Performance } \\
\text { scores are in the 10-29 range. }\end{array}$ \\
\hline
\end{tabular}

Table A.17. Institutional Mission Annual Report

\begin{tabular}{||l|l|l||}
\hline \multicolumn{1}{|c|}{ Category } & Performance Level & Significance \\
\hline \hline $\begin{array}{l}\text { Overall Institutional Mission } \\
\text { Performance }\end{array}$ & \multicolumn{1}{|c||}{ Level 6 } & $\begin{array}{l}\text { Some key indicators are close to benchmarks, some in } \\
\text { midrange, some lower. Trends are mixed. }\end{array}$ \\
\hline \hline Mission Area Performance & & \\
\hline ES\&H & Achievement $=78$ & \\
\hline & Key Indicators $=26$ & Key indicators in midrange or higher, trends positive \\
\hline & Cost Performance $=95$ & \\
\hline Management and Culture & Achievement $=95$ & \\
\hline & Key Indicators $=35$ & Some key indicators in midrange, trends mixed \\
\hline $\begin{array}{l}\text { Technical and Resource } \\
\text { Management }\end{array}$ & Achievement $=66$ & \\
\hline & Key Indicators $=27$ & $\begin{array}{l}\text { Key indicators midrange to lower, trends mostly } \\
\text { negative }\end{array}$ \\
\hline & Cost Performance $=83$ & \\
\hline External Relationships & Achievement $=72$ & \\
\hline & Key Indicators $=50$ & Some key indicators in midrange, trends mixed \\
\hline
\end{tabular}




\section{Appendix B: Other Applications}

In recognition of the diversity of the operations within FE and DOE, two hypothetical applications of the PIMM demonstrate the apparent utility of the approach to a diverse range of institutions and organizational Missions. The first application is the Strategic Petroleum Reserve Office (SPRO) within the Office of Fossil Energy and the other is $\mathrm{FE}$ as a whole.

\section{Strategic Petroleum Reserve Office (SPRO)}

SPRO is responsible for a large crude oil stockpile and has a Technology Mission to reduce U.S. vulnerability to the economic, national security, and foreign policy consequences of supply interruptions by discouraging supply disruptions as a policy tool of other nations, and by providing crude oil supplies to the United States in the event of a disruption due either to political, military, or natural causes. The Technology Mission and Goals of SPRO are well defined. While the application of the PIMM to SPRO seems straightforward, it is emphasized that the example shown below is highly hypothetical and has not been reviewed in detail by SPRO management.

Based on its strategic plan and single Technology Mission, no Technology Mission Area level is defined for SPRO. SPRO's Mission Goals which directly support its Technology Mission are:

- Establish and maintain a storage capability for 750 million barrels of crude oil.

- Establish and maintain a production capability for 4-1/2 million barrels/day of crude oil from storage on 15 days notice.
- Provide a storage capability for crude oil for other government agencies.

- Provide consultation to foreign governments under the International Energy Agreement.

- Provide consultation for establishing regional storage/distribution centers in the U.S. for finished oil products: e.g., heating oil.

As in the METC example in Appendix A, these Goals can be broken down into specific Targets where performance can be measured more directly. For example, five Targets are observed for SPRO which contribute to the Goal of production capability. This hypothetical example is illustrated in Table B.1.

The performance score for each Target is the product of the Target priority and the Target achievement. Definitions of Target priority and Target achievement were presented in Section 2 . The sum of scores for all Targets divided by the sum of Target priorities provides a numerical score of Goal level Target Achievement performance. As in the prior METC examples, it is possible to construct scoring systems and scores for SPRO in terms of achievement, risk, and cost performance. SPRO could have a rapid and unexpected drawdown in event of an emergency. There is considerable risk associated with such an event, and there are constant activities to maintain or increase reliability (reduce risk) of the drawdown process. This is amenable to a risk profile calculation. Also, a decision to upgrade equipment is expressible as risk management because the investment in equipment upgrades will result in a reduced risk for project or facility performance. 
Table B.1. Target Achievement Performance Evaluation for Production Capability Goal

\begin{tabular}{|l|c|c|c|}
\hline \multicolumn{1}{|c|}{ Target Description } & $\begin{array}{c}\text { Target } \\
\text { Priority }\end{array}$ & $\begin{array}{c}\text { Percent } \\
\text { Achievement }\end{array}$ & Points \\
\hline $\begin{array}{l}\text { Maintain existing sites to allow them to be ready to } \\
\text { draw down oil with 15 days notice }\end{array}$ & 9 & 100 & 900 \\
\hline $\begin{array}{l}\text { Periodically test installed physical equipment } \\
\text { associated with drawdown }\end{array}$ & 9 & 100 & 900 \\
\hline $\begin{array}{l}\text { Annually demonstrate capability to produce and } \\
\text { deliver 4.5 million barrels/day of crude oil from } \\
\text { storage on 15 days notice }\end{array}$ & 9 & 70 & 630 \\
\hline $\begin{array}{l}\text { Maintain an inventory of critical system replace- } \\
\text { ment components and periodically verify operability }\end{array}$ & 3 & 40 & 120 \\
\hline $\begin{array}{l}\text { Secure the facilities against trespass and vandalism, } \\
\text { and provide detection and a level of resistance to } \\
\text { armed intrusion }\end{array}$ & 3 & 10 & 30 \\
\hline \multicolumn{1}{|c|}{ Total } & 33 & & 2580 \\
\hline \hline
\end{tabular}

\section{Goal level Target Achievement Score $=(2580 / 33)=78$}

Application of the risk management concept to such a mission would be best done by the managers of the activity, and thus, for this example, we have chosen to show only SPRO's Target Achievement and cost performance measurements. A list of hypothetical scores for each of the five Goals comprising the SPRO Mission is presented in Table B.2.

The determination of SPRO Mission performance requires the roll up of the scores from each of the Goals, performed in a fashion similar to that used for the METC technology example in Appendix A.

The roll up requires a PBIS that correlates appropriate Mission performance levels with the scores of all of the Goals. A hypothetical example of a PBIS for the SPRO Technology Mission performance is shown in Table B.3.
Using this PBIS, the performance from Table B.2 is Level 8 because Storage and Production scores $>80$ and All Goals $>60$. Again, this example points to the ability of the PBIS to emphasize various Goals and the importance of using a Mission rationale in building more significance into the PBIS tables. This application to SPRO has considered only the Technology Mission. No effort was made to develop a SPRO example for the Institutional Mission.

\section{Office of Fossil Energy}

FE has seven reporting elements including six field sites and the headquarters organization. To determine the performance of $\mathrm{FE}$ as a whole, it is necessary to have inputs from each of the reporting elements. 
Table B.2. Goal Scores for SPRO Technology Mission

\begin{tabular}{||l|c|c|c||}
\hline \multicolumn{1}{|c|}{ Goal } & $\begin{array}{c}\text { Target } \\
\text { Achievement } \\
\text { Score }\end{array}$ & $\begin{array}{c}\text { Cost } \\
\text { Performance } \\
\text { Score }\end{array}$ & $\begin{array}{c}\text { Goal } \\
\text { Performance } \\
\text { Score (average) }\end{array}$ \\
\hline Storage & 93 & 86 & 90 \\
\hline Production & 82 & 79 & 80 \\
\hline Storage - other & 75 & 72 & 74 \\
\hline Consultation - foreign & 91 & 89 & 90 \\
\hline Consultation - domestic & 75 & 77 & 76 \\
\hline
\end{tabular}

Table B.3. PBIS for SPRO Technology Mission

\begin{tabular}{|c|l|}
\hline Level & \multicolumn{1}{|c|}{ Description } \\
\hline 10 & Storage and Production score $>95$ and all Goals $>70$ \\
\hline 8 & Storage and Production scores $>80$ and all Goals $>60$ \\
\hline 6 & Storage and Production scores $>70$ and all Goals $>50$ \\
\hline 4 & All Goals $>50$ \\
\hline 2 & One or more Goals $<50$ \\
\hline
\end{tabular}

Two Energy Technology Centers (Morgantown and Pittsburgh) and five other reporting elements (Bartlesville Project Office, Naval Petroleum \& Oil Shale Reserves, Metairie Site Office, Strategic Petroleum Reserve Project Office, and Headquarters) comprise FE, an Assistant Secretariat within the Department of Energy, as shown in Figure B.1. Each of the reporting elements, including the headquarters Assistant Secretariat, has both a Technology Mission and an Institutional Mission that contributes to the overall performance of FE. The object of this example is to demonstrate a method for rolling up the contributions of each of the reporting elements to determine an overall performance score for FE. Individual scores for each of the reporting elements are purely hypothetical and do not necessarily represent actual performance.

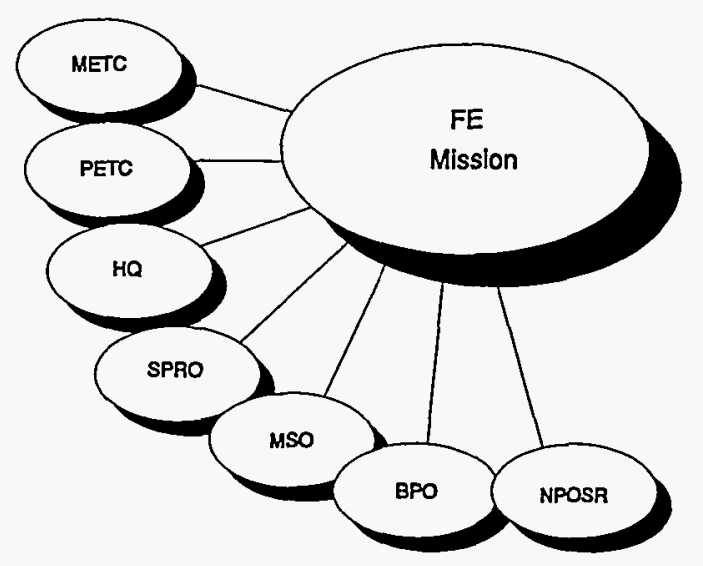

Figure B.1. Rollup for FE Mission

Note that the program office (HQ) must also develop performance measures which are independent of "field center" performance. 
A summary of the hypothetical performance scores for each reporting element is listed in Table B.4. This information would be directly provided in the annual performance report of each reporting element.

The next step in evaluating the Mission performance of FE is to develop a PBIS to define the composite scores of the reporting elements necessary to achieve specific levels of overall performance. An example of a PBIS for FE is provided in Table B.5, which incorporates a bias that METC and PETC, with the major RD\&D roles, must both perform well for $\mathrm{FE}$ to have a high-level score.

In this hypothetical example, the FE Technology Mission shows Level 8 performance.

Table B.4. Individual Performance for FE Reporting Elements

\begin{tabular}{||l|c|c||}
\hline \multicolumn{1}{|c|}{ Reporting Element } & $\begin{array}{c}\text { Technology } \\
\text { Mission Score }\end{array}$ & $\begin{array}{c}\text { Institutional Mission } \\
\text { Score }\end{array}$ \\
\hline \hline Morgantown Energy Technology Center & 9 & 6 \\
\hline Pittsburgh Energy Technology Center & 8 & 6 \\
\hline Bartlesville Project Office & 6 & 2 \\
\hline Naval Petroleum \& Oil Shale Reserves & 10 & 8 \\
\hline Metairie Site Office & 8 & 4 \\
\hline Strategic Petroleum Reserve Office & 8 & 10 \\
\hline Headquarters & 8 & 8 \\
\hline
\end{tabular}

Table B.5. Performance Based Indicator System for the FE Technology Mission

\begin{tabular}{|c|c|}
\hline Level & Description \\
\hline 10 & $\begin{array}{l}\text { METC and PETC have Level } 10 \text { Performance: At least two other } \\
\text { reporting elements have Level } 10 \text { Performance: No reporting element } \\
\text { has less than Level } 6 \text { Performance. }\end{array}$ \\
\hline 8 & $\begin{array}{l}\text { Either METC or PETC has Level } 9 \text { Performance and the other has } \\
\text { Level } 8 \text { Performance: At least one other Reporting element has at } \\
\text { least Level } 9 \text { Performance: No reporting element has less than Level } 6 \\
\text { Performance. }\end{array}$ \\
\hline 6 & All reporting elements have at least Level 6 Performance. \\
\hline 4 & $\begin{array}{l}\text { No more than one reporting element has less than Level } 6 \\
\text { Performance. }\end{array}$ \\
\hline 2 & Two or more reporting elements have less than Level 6 Performance. \\
\hline
\end{tabular}


This example illustrates the capability to emphasize the performance of specific reporting elements that are believed to have an dominant influence on the overall performance of $\mathrm{FE}$. Standards for determining performance at each level should be realistic and use a broad scale. Benchmarks for top level performance should correspond with the "best" industrial practice. By this we mean that benchmarks should be sought among companies that are the best in the world at new product development. Scores near the top of the PBIS scale should be unusual and should only be given when truly significant technology improvements occur. Similar to a "pegged" speedometer, a PBIS that consistently indicates performance at level 10 will not be useful in identifying activities that need improvement.

A composite score for FE's Institutional Mission can be determined by using a similar PBIS for all $\mathrm{FE}$ locations (including $\mathrm{FE} / \mathrm{HQ}$ ) as shown in Table B.6.
Applying the PBIS of Table B.6 to the scores of Table B.4, the FE Institutional Mission Performance is Level 2.

Although this PBIS is similar to the PBIS for the Technology Mission, there are some significant differences. In Table B.6, both HQ and SPRO are considered to be "critical" reporting elements and their performance has been emphasized. This means more reporting elements must achieve high performance scores for the overall FE Institutional Mission score to be high. Two points should be re-emphasized. First, a low score means there is significant opportunity for improvement. Secondly, scores should not be used for punishment or rewards.

The success of the two applications suggests the PIMM methodology is widely applicable throughout DOE and, perhaps, to other government agencies. The concept of risk management exhibits a wide applicability.

Table B.6. PBIS for the FE Institutional Mission

\begin{tabular}{|c|l||}
\hline Level & \multicolumn{1}{c|}{ Description } \\
\hline 10 & $\begin{array}{l}\text { HQ, SPRO, METC and PETC have Level 10 Performance: At least two } \\
\text { other reporting elements have Level 8 Performance: No reporting elements } \\
\text { have less than Level 6 Performance. }\end{array}$ \\
\hline 8 & $\begin{array}{l}\text { HQ, SPRO, METC or PETC and one other reporting element have Level } 8 \\
\text { Performance: No other reporting elements have less than Level } 6 \\
\text { Performance. }\end{array}$ \\
\hline 6 & All reporting elements have at least Level 6 Performance. \\
\hline 4 & No more than one reporting element has less than Level 6 Performance. \\
\hline 2 & Two or more reporting elements have less than Level 6 Performance. \\
\hline
\end{tabular}




\section{Appendix C: Financial Considerations}

Measurements will need meaningful and consistent financial parameters and data. Since the current financial reporting structure within DOE is based on a Budget and Reporting (B\&R) classification system aligned with technology or work related areas, and typically these $B \& R$ structures do not line up with Technology Mission Areas, selecting the parameters to be used and methods to collect the data will need careful consideration. This Appendix provides some financially-based insights that will need to be considered in the application of this particular methodology.

In order for this methodology to work within METC, it is necessary to collect data from within the current $B \& R$ structure and to relate it to METC's Mission Areas. The IGCC system component is currently funded from multiple sub-program B\&R activities, i.e., AA05, AA15, AA35, AA55, and AA85 as well as multiple lower-level B\&R's within the sub-programs. As can be seen, the current structure (FY94) does not readily lend itself to the collection of data at the Mission Area (Product line) level. However, the $B \& R$ structure is being changed and in future years the overlay of $\mathrm{B} \& \mathrm{R}$ and Mission Areas should be easier.

METC considered several options to collect data and relate it to Mission Areas. For example, the possibility of utilizing the ninth digit of the $\mathrm{B} \& \mathrm{R}$ for special coding purposes was explored. Consideration was also given to utilizing certain fields within the Business Management and Information System (BMIS) for this purpose. After considering these options as well as other alternatives, it was determined that the most practical solution was to realign the current B\&R system to focus on METC's Products. It is important for each reporting element to determine the most practical method of collecting data for its Mission Areas or Products.

\section{Financial Parameters}

There are three types of funding categories that are potentially useful as financial parameters to support the measurement process. These types and their functional descriptions are as follows:

- Congressional Appropriations: These are the funds actually allocated to a Federal organization for use in performing its Missions. Funding from an appropriation act is referred to as budget authority (BA) and also as obligational authority.

- Obligations: Funding authority under a contractual arrangement that authorizes the incurrence of costs necessary to accomplish a specific purpose, such as in the production of a particular product or service. In the traditional accounting sense, obligations are represented as amounts of orders placed, contract or financial instruments awarded, as well as other types of financial transactions.

- Costs: Cost is the financial measurement of resources used in accomplishing a specified purpose, such as performing a service, carrying out an activity, acquiring an asset, or completing a unit of work or a specific project. Costs are recorded in the accounting system on an accrual basis. Accrual accounting recognizes an expense in the period in which it is incurred regardless of when the payment of the cost is made.

\section{Reporting Options}

Presently, there is extensive financial reporting which ensures that money is spent only where authorized and provides exact accounting for expenditures. However, performance measurement must address the question, "Are resources 
being applied effectively to support the Mission?" To serve this end, it becomes necessary to relate Mission(s) performance to both quantities of dollars and dollar flow rates.

There are implications that can be obtained from reporting and comparing periodic changes in financial status, as summarized by the following:

1. New (actual) BA plus carryover BA represents the total available funding which is the basis for all associated work activities and cost evaluation parameters. Changes in total funding could trigger a need to replan work activities and performance measures. If the appropriation is delayed from the beginning of the fiscal year or is different than expected, there can be significant programmatic and/or operational implications. Supplemental appropriations can also add or withdraw BA during the year.

2. Comparison of Actual Obligations to the Execution or Obligation Plan: This reflects the ability to plan and execute work activities from a financial perspective.

3. Comparison of Costs to the amounts Obligated: This is one measure of whether the work is progressing. This comparison can provide early indication(s) as to whether progress is going well or poorly.

4. Comparison of Costs to the Cost Plan: This is an indication of the implementor's (e.g., the contractor's) ability to plan and execute (to the plan) the actual work activities. Deviations often reflect either significant work progress or work problems.

Note: These are points of comparison of an informative nature which state the financial condition (i.e., dollar values, actual vs. plan, estimates, etc.). They do not address the need to determine effectiveness.
5. Comparison of Costs (inputs) to overall Performance (outcomes): This is the principal means to address effectiveness, as opposed to other less informative relationships/ratios, such as--inputs to outputs, outputs to outcomes, outcomes to impact, etc. In general, effectiveness is determined by analyses which take into consideration all relevant parameters (i.e., risk reduction, progress achievements, cost evaluations, Mission/Goal accomplishments, etc.). The Cost Performance approach used in this report is one way to address this need.

The funding used in these evaluations must be partitioned by at least the Mission Area (product) in order for the evaluation to have meaning in measuring the effectiveness of the organization at fulfilling its Mission. The implementation will require a slight extension of the present budget planning process - the responsible manager(s) will define the funds which benefit specific Mission Areas/products. Where one activity benefits multiple products, the manager will apportion the funds appropriate to each product. The specific processes to be followed from this point depend upon the types of evaluations to be performed and may be "customized" by each organization. Some generalizations are offered below.

- BA-based evaluations may be done manually since changes to BA occur only infrequently and are generally tied to legislative language.

- Obligation-based evaluations should use the BMIS as the information reference source. Some of the unused BMIS data fields could be used to capture the portion of the BMIS line item serving each product.

- Cost-based evaluations are the most significant challenge to support with data - and appear to be of the most value. Cost data currently exist in several places, but getting cost data correlated to the designated 
Mission Area/product does not appear to be straightforward within the existing financial system. The use of DISCAS or METC's Fact Sheet database appear to be able to service this need.

\section{Data Collection Guidelines}

The following are suggested as guidelines to facilitate the processes of developing financial data to support the measurement process. The "best" financial data collection process will:

- Aggregate data by product, i.e. Mission Area for a valid measurement of the financial and Mission effectiveness of the organization.

- Automate and collect data on at least the reporting frequency. Monthly data may be required by the project manager to assure a reasonable level of awareness of significant events, but the evaluations of the data for measurement purposes do not need to be reported monthly.

- Support and service the operational and cost performance measures of the organizational unit. Current practices only reflect administrative activities and financial record keeping for the institution as a whole.

- Be based upon, or relate directly to, the $B \& R$ structure. The Federal infrastructure appears wedded to the $B \& R$ structure and a measurement system should utilize the existing $B \& R$ structure to be acceptable.

- Be useable by all DOE sites. The measurement processes designed for use at METC should be generic enough to have applicability at other Federal sites. 


\section{Appendix D: Glossary of Terms}

A number of specialized terms and acronyms were used by the team to generate this report and are defined here. Two references on effectiveness measurements as applied to governmental organizations were used in the early work of the team. Both of these have provided definitions and these "other" definitions are not always consistent with the team definitions. Where they exist, these definitions are provided in the OTHER DEFINITION column below; they may help the reader relate the concepts in this report to these two references:

1. Elizabeth Smedley letter of October 5, 1992 on Performance Measures as related to the CFO Act.

2. D.J. Duquette and A.M. Stowe paper; Enter the Era of Performance Measurement Reporting; Government Accountants Journal, Summer 1992, pages 19 through 28.

The Primary Terms are those critical to the understanding of this report and also define the hierarchy of the activities used in developing the cited measurements. The last two subject areas respectively define terms used in planning activities and in the finance area.

\section{PRIMARY TERMS}

Mission

Mission Areas

Goals

Targets

Measurement

\section{TEAM DEFINITION}

\section{General Terms}

The overall purpose of the activities undertaken by the organization.

The more focussed, "sub-Mission" subject areas that, collectively, fulfill a Mission. For METC, these are Product Lines.

Specific long range objectives which, if attained, will collectively fulfill a Mission Area.

Quantifiable, specific, typically short range objectives or activities that need to be done in order to achieve a Goal.

The process used to assess the degree of achievement of Targets or attainment of Goals, Mission Areas, and Missions.

\section{OTHER DEFINITION}

The overall purpose for which the reporting entity exists. ${ }^{2}$

General but measurable, overall plan or policy needed to support the Mission. ${ }^{1}$

\section{None}

Quantifiable steps aimed at overcoming the program's implementation barriers and achieving the Goal. ${ }^{2}$

None 
PRIMARY TERMS

PIMM, Performance

Improvement

Measurement

Methodology

PBIS, Performance

Based Indicator

System

Key Indicator

Technology Risk

Cost Performance

Impact

Input

Output

Outcome

Significance
TEAM DEFINITION

The methodology proposed in this report for measuring performance.

A numerical scale, based on textual descriptions of achieved levels of performance, used to assign scores.

High level measure that relates closely to long range goal achievement.

A Key Indicator for a Technology Mission. The chance of the new technology not meeting the desired performance for the application and in the time frame intended.

The expected or planned cost of a specific outcome compared to the its actual cost. See text in Appendix A for specific definitions used in the PIMM.

\section{Performance Indicators}

The consequences associated with reaching an objective or accomplishing a Mission; usually consequences outside the organization managing the program. Identical to "outcome" as defined below.

The resources put into the program, i.e., funding, manpower, etc.

The specific products of an activity, such as Targets achieved.

The importance of an activity.
OTHER DEFINITION

None

None

None

None

None
The degree of achievement of program Goals through outcomes. ${ }^{2}$ The degree of achievement or measure of accomplishment of program Goals and objectives. ${ }^{1}$

The resources put into the program, i.e., funding, manpower, etc. ${ }^{1,2}$

The number of goods or services produced or transactions completed. ${ }^{1,2}$

The quantity of direct results. ${ }^{1,2}$

The trends in achievement of program Goals over time. ${ }^{2}$ 
PRIMARY TERMS

Efficiency

Effectiveness

Relevance

Sustainability

TERM

Multi-Year Plan

Program Plan

Product plan

PIP, Program Implementation Plan

Fact Sheets

Strategic Plan

\section{TEAM DEFINITION}

\section{Performance Measures}

The ratio of outputs to inputs; note this is consistent with usual engineering use of the term while the "other" definition is the inverse of the usual meaning.

The ratio of "value" of outputs or outcomes to inputs.

The relation to the function being measured.

The ability to maintain a level of achievement.
The ratio of program outputs per unit of program outcome. ${ }^{2}$

\section{OTHER DEFINITION}

The ratio of inputs to outputs. ${ }^{2}$

The ratio of program outcome to program impact. $^{2}$

The measure of endurance of program benefit over time. ${ }^{2}$

\section{Program / Project / Product Planning}

The description of, and rationale for, the Mission, Mission Areas, and Goals which will be pursued over a nominally 20 year time frame, and the strategies to accomplish the Mission. This usually includes situational analyses for the organization in question.

Implementation plans in the various Mission Areas covering usually a five year cycle; it includes discrete objectives, quantitative Goals, schedules, and budgets.

The program office definition of a specific program entity; this is now an obsolete term.

The description of the activities necessary to develop a product to the point of commercialization.

The field office definition of the particular projects planned to reach the objectives for a specific technology.

Individual project descriptions which include contract, work scope, schedule, funding, cost plans, and status information. 
TERM

Appropriation

BMIS, Business Management Information System

B\&R, Budget and Reporting classification number

Commitment

Costs

Expenditures

DISCAS, Departmental Integrated Standardized Core Accounting System

FIS, Financial Information System

Obligations

PR, Procurement Request

Uncosted

Unobligated

\section{TEAM DEFINITION}

\section{Budget/Finance}

The budget authority (BA) provided by Congress through an Appropriation Act which provides funding in designated program areas (i.e., B\&R's).

A data base used in DOE-Fossil Energy to provide detailed information on procurement execution planning and implementation.

The number identifying the level of detail for Congressional appropriations. It corresponds with program structure and identifies the funding control and reporting levels.

A transaction initiated by a procurement request (PR) which reserves funding for a procurement action.

The value of goods or services provided, or materials received, as billed to the government.

Synonymous with "outlay" or "disbursement," outlays during a fiscal year may be for payment of obligations incurred in prior years or in the same fiscal year. These are the actual funds paid out by the U.S. Treasury.

The standard accounting system utilized by DOE.

The DOE system that consolidates and reports on all of the accounting systems in DOE; this is likely the best source of cost information.

The amounts of orders placed, contracts awarded, services received, and similar transactions during a given period that will require payments during the same or a future period.

The document used to initiate procurement actions.

The portion of an obligation which has not been costed (i.e., not liquidated).

The portion of Budget Authority (BA) which has not been obligated; note that this category also includes funds that have been committed, but not yet obligated. 


\section{Appendix E: Example Risk Analysis for IGCC Goal \#1 (Goal 2000)}

The severity of the technical challenge for a given subsystem or major component of a technology is estimated by the technology developer. However, customer inputs are required to allow a priority factor to be brought into the risk measurement. For example, a customer may require a certain overall system reliability to install a new IGCC plant. If reliability is the most significant of all the user requirements for the system (among others such as plant cost and environmental performance), subsystems that determine this reliability could be assigned a "high" priority level using definitions such as those shown in Table 2.3.

A process for calculating a hypothetical risk for an IGCC system to meet IGCC Goal 2000 at some particular time in the development is shown in Table E.1. Normally this methodology would be applied to a specific plant design, for example, an IGCC system using a specific gasifier and gas cleanup system. The methodology of the risk analysis used in the table is as follows:

- A description is developed for the product or technology which breaks down the product into subsystems or major components.

- System level user requirements are defined and prioritized.

- The strength of the linkages between each subsystem and the user requirements are identified to show how closely the user requirements relate to subsystems or major components of the product.

- The "importance" of the subsystem is then determined by multiplying the priority of each user requirement by the "linkage" of the subsystem to that requirement, and then summing these products for each subsystem.

- The next step is to identify the major technical barriers that are sources of risk for every subsystem, using the system developer and customer judgments. The "technical difficulty" of meeting the design requirements for each subsystem is then estimated.

- A risk score for each subsystem is then calculated by multiplying the "importance" times the "technical difficulty". The overall product or technology risk score is then calculated by summing the subsystem scores.

The resulting risk score or risk level is indicative of the overall risk to the customer in meeting requirements if the technology were to have to be used today. The score is the risk at a particular stage of technology development, that is, at a particular time. The risk scale is somewhat arbitrary. While it might be possible to derive an absolute risk scale, no attempt has been made to do so for this report.

The primary utility of the risk score is to measure each system's development progress by noting the change in the score with time during the RD\&D process. The magnitude of the system risk score is a function of the number of system requirements and subsystems evaluated in the risk development. Consequently, risk scores are not directly comparable across systems employing different technologies or serving different applications. Risk analysis results can be used to assess different approaches to solving problems with a specific technology, but should not be used to compare technologies for making resource decisions. 
Table E.1. Example Risk Analysis for a Specific IGCC System:

Technology Risk Related to User Requirements

\begin{tabular}{||l|c|c|c|c|c||}
\hline \multirow{2}{*}{$\begin{array}{l}\text { System User Requirements } \\
\text { (yr 2030) }\end{array}$} & $\begin{array}{c}\text { User } \\
\text { Priority }\end{array}$ & \multicolumn{4}{|c|}{ Linkage of Subsystem to User Requirements } \\
\cline { 3 - 7 } & $\begin{array}{c}\text { Gasifier } \\
\text { System }\end{array}$ & $\begin{array}{c}\text { Particulate } \\
\text { Removal }\end{array}$ & $\begin{array}{c}\text { Sulfur } \\
\text { Removal }\end{array}$ & $\begin{array}{c}\text { Turbine } \\
\text { System }\end{array}$ \\
\hline Capacity (output) & 3 & 9 & - & - & 9 \\
\hline Availability >85\% & 9 & 9 & 1 & 9 & 9 \\
\hline Efficiency >52\% & 3 & 3 & 1 & 3 & 9 \\
\hline Costs <\$1000/kw & 9 & 9 & 1 & 3 & 9 \\
\hline Environmental performance & 9 & 1 & 1 & 9 & 3 \\
\hline \hline $\begin{array}{l}\text { Importance } \\
\text { (Sum of Priority x Linkage) }\end{array}$ & & $\mathbf{2 0 7}$ & $\mathbf{3 0}$ & $\mathbf{1 9 8}$ & $\mathbf{2 4 3}$ \\
\hline $\begin{array}{l}\text { Technical Difficulty } \\
\text { of Design Requirements }\end{array}$ & & 1 & 3 & 9 & 1 \\
\hline \hline $\begin{array}{l}\text { Risk } \\
\text { (Technical Difficulty } x \\
\text { Importance) }\end{array}$ & & $\mathbf{2 0 7}$ & $\mathbf{9 0}$ & $\mathbf{1 7 8 2}$ & $\mathbf{2 4 3}$ \\
\hline \hline $\begin{array}{l}\text { Risk Summary for System } \\
\text { (Sum of subsystem risks) }\end{array}$ & $\mathbf{2 3 2 2}$ & & & & \\
\hline \hline
\end{tabular}

${ }^{1}$ High=9,Medium=3,Low=1 for Priority, Linkage, and Technical Difficulty Levels

It is important to note that the general methodology for risk calculation is highly adaptable. The table above represents one way to make the calculation. Alternative tabulations using the same general approach, but different attributes of the technical system studied, are possible and may be better for some technology areas. 


\section{Appendix F: Performance Based Budgeting}

This appendix offers an approach to performance based budgeting which incorporates the measurement results of the PIMM. The basis for performance based budgeting is a combination of the PIMM with a new budget and reporting (B\&R) system and with a modified Internal Review Budget (IRB) request form. The new B\&R system is focused on products (Mission Areas) rather than programs and is consistent with the product lines identified in the PIMM. This $B \& R$ system is similar to that described in Appendix C Financial Considerations.

An example of the modified IRB request form is presented on the following page. For the Technology Mission, the decision unit for IRB inputs would be at the Mission Area level (i.e., IGCC, PFBC, EFCC, etc.). Other modifications include additions of performance indicators, performance goals, past and current performance data. The modified IRB request form also includes estimates of performance for the funding year (in this case, FY 1996) based on the level of funding. Quantitative performance estimates and narrative descriptions of summary of impacts relate funding levels to both Target Achievement for the funding year and long term Risk Reduction which is linked to product commercialization.

The hypothetical data presented on the following page illustrates how an FY 1996 IRB input might appear for the IGCC Mission Area. This example uses the most recent full year
(FY 1993) of measurement data from the PIMM to show actual performance. Although FY 1994 performance data would probably not be available when the FY96 IRB input is required, performance through about half of the fiscal year could be used to project performance at the year's end. No performance data would be available for FY 1995.

As with the current IRB inputs, the basis for the budget request is the program planning level (PPL). This amount of funding is consistent with METC's Risk Management Profile for delivering a commercial product by a particular date. If the $O M B$ target funding level is different from the PPL, the impact of reduced funding must be described both in the expected performance goals shown near the right, central portion of the table and in the narrative summary of impact shown near the bottom of the table. Specifically, the impact summary contains a statement of the delay in commercialization of the product caused by the decreased funding. Both of these factors are illustrated in the example. The impact of a further reduction of funding to the decrement level is described in a similar fashion.

The use of PIMM performance indicators (Target Achievement, Risk Reduction, and Cost Performance) in the IRB also provides an opportunity to numerically illustrate the impact on performance goals of specific funding reductions. 


\section{Department of Energy \\ FY 1996 Internal Review Budget Request \\ Output Measurement and Impact Summary \\ (Submitted in March, 1994)}

\section{Appropriation: Fossil Energy R\&D}

Decision Unit: Integrated Gasification and Combined Cycle (IGCC)

\begin{tabular}{|c|c|c|c|c|c|c|c|}
\hline \multicolumn{8}{|c|}{$\begin{array}{c}\text { Resource Profile } \\
\text { (Dollars in Thousands) }\end{array}$} \\
\hline \multirow{3}{*}{\multicolumn{2}{|c|}{ Budget Authority (BA): }} & \multirow{2}{*}{$\begin{array}{l}\text { FY } 1993 \\
\text { (Actual) }\end{array}$} & \multirow{2}{*}{$\begin{array}{l}\text { FY } 1994 \\
\text { (Actual) }\end{array}$} & \multirow{2}{*}{$\begin{array}{c}\text { FY } 1995 \\
\text { (PPL) }\end{array}$} & \multicolumn{3}{|c|}{ FY 1996} \\
\hline & & & & & Decrement & OMB Target & PPL \\
\hline & & 43,026 & 45,233 & 50,000 & 36,000 & 40,000 & 50,000 \\
\hline \multicolumn{8}{|c|}{$\begin{array}{l}\text { Technology Goal } \\
\text { Commercialization of IGCC power systems offering continuing improvement in efficiency to } 52 \% \text { in the year } 2020 \text {. In addition, the } \\
\text { IGCC systems will be available at reduced capital cost (less that } \$ 1,000 / \text { kilowatt in the year } 2020) \text { and constantly improving } \\
\text { environmental performance. }\end{array}$} \\
\hline \multicolumn{8}{|c|}{ Performance Measures } \\
\hline \multirow{2}{*}{\multicolumn{2}{|c|}{ Performance Indicators }} & \multirow{2}{*}{$\begin{array}{l}\text { FY } 1993 \\
\text { (Actual) }\end{array}$} & \multirow{2}{*}{$\begin{array}{c}\text { FY } 1994 \\
\text { (Projected) }\end{array}$} & \multirow{2}{*}{$\begin{array}{c}\text { FY } 1995 \\
\text { (Unavailable) }\end{array}$} & \multicolumn{3}{|c|}{ FY 1996 Performance Goals } \\
\hline & & & & & Decrement & OMB Target & PPL \\
\hline \multicolumn{2}{|c|}{ Target Achievement } & 88 & 95 & - & 65 & 85 & 100 \\
\hline \multicolumn{2}{|l|}{ Risk Reduction } & 83 & 87 & - & 55 & 78 & 100 \\
\hline \multicolumn{2}{|c|}{ Cost Performance } & 95 & 91 & - & - & - & - \\
\hline \multicolumn{2}{|c|}{ Average Performance } & 89 & 91 & - & 60 & 82 & 100 \\
\hline \multicolumn{8}{|c|}{ Summary of Impact } \\
\hline PPL: & \multicolumn{7}{|c|}{$\begin{array}{l}\text { Continue the development of advanced high performance power systems consistent with the Department's efficiency } \\
\text { and capital cost goals and to meet CAAA requirements in a timely manner. In order to meet our technical goals, } \\
\text { major activities must be initiated and/or completed during FY 1996. They include completing the detailed design of } \\
\text { the GPIF, awarding an AE procurement to oversee construction of the GPIF, constructing the multicomponent test } \\
\text { facility on the PSDF, completing component development activities on particulate removal subsystems, completing } \\
\text { sidestream tests HGCU tests at TIDD, completing zinc ferrite sorbent development activities, planning a series of } \\
\text { system studies for process characterization, and awarding a procurement for coal gas combustion studies for ATS } \\
\text { applications. }\end{array}$} \\
\hline OMB Target: & \multicolumn{7}{|c|}{$\begin{array}{l}\text { Funding at the OMB Target level will result in a performance score of only } 82 \text { relative to the PPL level. With } \\
\text { regards to the Departments PPL product plans, this reduced funding will delay the commercialization of the final } \\
\text { IGCC products by about } 1 \text { year. Specific activities that will be delayed or require schedule expansions include: } \\
\text { complete the detailed design of the GPIF, complete construction of the multicomponent test facility on the PSDF, } \\
\text { complete component development activities on particulate removal subsystems, complete sidestream tests HGCU } \\
\text { tests at TIDD, and complete zinc ferrite sorbent development activities. }\end{array}$} \\
\hline Decrement: & \multicolumn{7}{|c|}{$\begin{array}{l}\text { Funding at the Decrement level will result in a performance score of only } 60 \text { relative to the PPL level. With regards } \\
\text { to the Departments PPL product plans, this reduced funding will delay the commercialization of the final IGCC } \\
\text { products by about } 2 \text { years. Specific activities that will be delayed or require schedule expansions include: complete } \\
\text { the detailed design of the GPIF, initiate AE procurement to oversee GPIF construction, complete construction of the } \\
\text { multicomponent test facility on the PSDF, initiate the HGCU tests in the PSDF, complete component development } \\
\text { activities on particulate removal subsystems, complete sidestream tests HGCU tests at TIDD, and complete zinc } \\
\text { ferrite sorbent development activities. }\end{array}$} \\
\hline
\end{tabular}

